\title{
Coupling sulfur and oxygen isotope ratios in sediment melts across the Archean-Proterozoic transition
}

\author{
Janne Liebmann ${ }^{\mathrm{a}, *}$, Christopher J. Spencer ${ }^{\mathrm{b}, \mathrm{c}}$, Christopher L. Kirkland ${ }^{\mathrm{a}}$, \\ Claire E. Bucholz ${ }^{\mathrm{d}}$, Xiao-Ping Xia ${ }^{\mathrm{e}}$, Laure Martin ${ }^{\mathrm{f}}$, Nami Kitchen ${ }^{\mathrm{d}}$, \\ Leonid Shumlyanskyy ${ }^{g, h}$ \\ ${ }^{a}$ Timescales of Mineral Systems Group, The Institute for Geoscience Research (TIGeR), School of Earth and Planetary Sciences, \\ Curtin University, Perth, Australia \\ ${ }^{\mathrm{b}}$ Earth Dynamics Research Group, The Institute for Geoscience Research (TIGeR), School of Earth and Planetary Sciences, Curtin \\ University, Perth, Australia \\ ${ }^{\mathrm{c}}$ Department of Geological Sciences and Geological Engineering, Queen's University, Kingston, Canada \\ ${ }^{\mathrm{d}}$ Division of Geological and Planetary Sciences, California Institute of Technology, Pasadena, USA \\ e State Key Laboratory of Isotope Geochemistry, Guangzhou Institute of Geochemistry, Chinese Academy of Sciences, Guangzhou, China \\ ${ }^{\mathrm{f}}$ Centre for Microscopy, Characterisation, and Analysis, ARC Centre of Excellence for Core to Crust Fluid Systems (CCFS), University \\ of Western Australia, Perth, Australia \\ ${ }^{\mathrm{g}}$ School of Earth and Planetary Sciences, Curtin University, Perth, Australia \\ ${ }^{\mathrm{h}}$ M.P. Semenenko Institute of Geochemistry, Mineralogy and Ore Formation, Kyiv, Ukraine
}

Received 15 December 2020; accepted in revised form 21 May 2021; available online 28 May 2021

\begin{abstract}
The Archean-Proterozoic transition marks a time of fundamental geologic, biologic, and atmospheric changes to the Earth system, including oxygenation of the atmosphere (termed the Great Oxygenation Event; GOE), and the emergence of continents above sea level. The impacts of the GOE on Earth's surface environment are imprinted on the geologic record, including the disappearance of mass-independent fractionation of sulfur isotopes (S-MIF). Temporally overlapping geologic and geochemical observations (e.g. a change in oxygen isotope ratio of sediments and an increase in subaerial volcanism) imply the widespread subaerial emergence of continents was coeval with atmospheric oxygenation. Here we present triple sulfur isotope ratios in pyrite and oxygen isotope ratios in garnet and zircon in a global suite of Archean and Proterozoic granitoids derived from the partial melting of sedimentary protoliths. These crustal melts record an increase in average garnet and zircon $\delta^{18} \mathrm{O}$ from $7.2 \%$ before $2.3 \mathrm{Ga}$ to $10.0 \%$ post-2.3 Ga. Pre-2.3 Ga granitoids show small S-MIF signatures with $\Delta^{33} \mathrm{~S}$ ranging from $-0.29 \%$ to $0.13 \%$, whereas post- $2.3 \mathrm{Ga}$ granitoids record S-MDF (i.e. $\Delta^{33} \mathrm{~S}=0 \%$ ). The combination of sulfur and oxygen isotope signatures in the same sample with zircon $\mathrm{U}-\mathrm{Pb}$ geochronology provides new insights on a potential causal link between the emergence of continents and Paleoproterozoic atmospheric oxygenation.
\end{abstract}

(C) 2021 Elsevier Ltd. All rights reserved.

Keywords: Atmospheric oxygenation; Great Oxygenation Event; Continental emergence; Archean Proterozoic boundary; Oxygen Isotopes; Multiple sulfur isotopes; S-type granites; Strongly peraluminous granites

\footnotetext{
* Corresponding author.

E-mail address: janne.liebmann@curtin.edu.au (J. Liebmann).
} 


\section{INTRODUCTION}

The oxygenation of the Earth's atmosphere and oceans irreversibly changed many major biogeochemical cycles (e.g. Fe, S, Mn) (Pufahl and Hiatt, 2012) and provided the base for a highly efficient aerobic metabolism that allowed the development of complex life (Catling et al., 2005). During the Great Oxygenation Event (GOE) ( 2.3 Ga; Luo et al., 2016, c.f. Gumsley et al., 2017) atmospheric oxygen increased from $<0.001 \%$ of the present atmospheric level (PAL) (Pavlov and Kasting, 2002) to 10-40\% PAL (Kump, 2008), or perhaps much higher approaching 100\% PAL (Harada et al., 2015, and references therein). The mechanism that led to atmospheric oxygenation remains controversial. Proposed scenarios for oxygenation include: (1) an increase in $\mathrm{O}_{2}$ production (i.e. through the emergence of oxygenic photosynthesis) (Ward et al., 2016), (2) a decrease in $\mathrm{O}_{2}$ consumption (e.g. through changing redox state of volcanic gases, increased burial of organic carbon, or decreased pyrite weathering) (Holland, 2002; Bekker and Holland, 2012), and (3) a combination of both these processes (through enhanced oxygenic photosynthesis combined with increased carbon burial) (Campbell and Allen, 2008). One source of dispute is the timing of the evolution of oxygenic photosynthesis - suggestions range from $>3.7$ Ga to immediately preceding atmospheric oxygenation (Rosing and Frei, 2004; Lyons et al., 2014; Planavsky et al., 2014; Ward et al., 2016; Fischer et al., 2016; Warke et al., 2020). Previous studies imply that the widespread emergence of continents above sea level is temporally correlated with atmospheric oxygenation (Kump and Barley, 2007). Furthermore, it has been proposed that the subaerial emergence of continents may have led to a flux of life-essential nutrients into the ocean supporting a boost in photosynthetic activity (Campbell and Allen, 2008; Hao et al., 2020).

Multiple sulfur isotopic signatures are a sensitive tracer for atmospheric oxygen levels (Farquhar et al., 2000). Some sulfur-bearing minerals (predominantly sulfides and minor sulfates) in metasedimentary rocks deposited before the GOE display mass-independent fractionation of sulfur (SMIF), whereas those deposited after the GOE exclusively display mass-dependent fractionation (S-MDF) (Farquhar et al., 2000; Johnston, 2011). Although the exact mechanism is currently not known, S-MIF signatures are thought to be generated in the atmosphere through ultraviolet photolysis of gas molecules (Lyons, 2007; Whitehill et al., 2015). The establishment of an ozone shield as a consequence of atmospheric oxygenation led to the blocking of UV radiation and attenuation of the photolysis of volcanic sulfur species (Farquhar et al., 2000). In addition, enhanced oxidative weathering of sulfides and the formation of oceanic sulfates facilitated the production of highly fractionated sulfides by sulfur-metabolizing bacteria supporting the generation of S-MDF signatures (Guo et al., 2009). Recent studies show that fluctuations in atmospheric oxygen levels are also captured in the igneous rock record; namely, through transport of S-MIF into the crust (Bekker et al., 2009; LaFlamme et al., 2018a; Bucholz et al., 2020), and a change in oxygen fugacity of strongly peraluminous granites (Bucholz et al., 2018).

Broadly coeval with atmospheric oxygenation, the average oxygen isotope ratio of global felsic magmas (recorded by zircon $\delta^{18} \mathrm{O}$ ) increases (Valley et al., 2005). The oxygen isotopic composition of a magma is sensitive to the recycling of supracrustal material that interacted with surface water (Taylor, 1980). Igneous zircon in high-temperature equilibrium with mantle-derived melts (e.g. kimberlites) has remarkably homogenous $\delta^{18} \mathrm{O}$ values which average $5.3 \pm 0.6 \%$ (Page et al., 2007) relative to standard mean ocean water (VSMOW). Supracrustal material (e.g. sedimentary and volcanic rocks), in contrast, has a wide range of $\delta^{18} \mathrm{O}$ values $(\sim 0-40 \%)$ with most reservoirs being elevated in $\delta^{18} \mathrm{O}$ relative to the mantle (Savin and Epstein, 1970). Hence, assimilation of supracrustal material commonly results in magmas with elevated $\delta^{18} \mathrm{O}$ compared to mantle-derived magmas. An increase in average $\delta^{18} \mathrm{O}$ of zircon in the Paleoproterozoic has been recognized for over a decade (Valley et al., 2005). Contrasting models have been suggested to account for this increase in $\delta^{18} \mathrm{O}$; (1) the formation of high $\delta^{18} \mathrm{O}$ sediments (and melts that have assimilated such sediments) potentially linked to enhanced subaerial weathering and erosion related to the widespread emergence of continents above sea level (Spencer et al., 2019; Liebmann et al., 2021a), and (2) enhanced crustal recycling associated with the onset of collisional tectonics (Spencer et al., 2014). However, Paleoproterozoic high $-\delta^{18} \mathrm{O}$ sediment melts do not show a concomitant depletion in radiogenic ${ }^{176} \mathrm{Hf}$, as would be expected if the increase in $\delta^{18} \mathrm{O}$ was related to enhanced supracrustal recycling (Liebmann et al., 2021a). Therefore, a change in sediment oxygen isotope composition, potentially associated with the subaerial emergence of continents (Bindeman et al., 2018), seems to be the likely driver for the Paleoproterozoic increase in average zircon $\delta^{18} \mathrm{O}$ (Spencer et al., 2019; Liebmann et al., 2021a).

We explore a potential link between the emergence of continents above sea level and atmospheric oxygenation through a coupled analysis of proxies for atmospheric oxygen level (sulfur isotopes) and sedimentary recycling (oxygen isotopes) in Archean to Mesoproterozoic sediment-derived granitoids (i.e. granitoids that partially or wholly derived from the partial melting of metasediments). The oxygen and sulfur isotope ratios in sediment-derived granitoids are strongly influenced by the isotopic composition of their sedimentary source rocks (Bindeman, 2020; Bucholz et al., 2020). Hence, sedimentderived granitoids provide a high-fidelity record of these isotopic signatures in bulk siliciclastic sediments that can be tied to magmatic crystallization ages. Furthermore, the isotope ratios captured by granitoids are relatively unaffected by secondary alteration processes, in contrast to those recorded by sediments. Here we present both multiple sulfur isotope ratios measured in pyrite, as well as, zircon and garnet oxygen isotope ratios within the same sample for a globally distributed suite of sedimentderived granitoids. The combination of these proxies with 
zircon $\mathrm{U}-\mathrm{Pb}$ geochronology allows us to provide new insights into the coupled behaviour of crustal, biogenic, and atmospheric evolution.

\section{MATERIALS AND METHODS}

\subsection{Sample context}

Samples of this study derive from various localities within the Superior, North China, West African, and East European Cratons, and the Yavapai province (USA). The sample areas were selected based on previous documentations of sediment-derived melts in these regions.

Granitoids containing at least one peraluminous indicator mineral (e.g. garnet, muscovite, cordierite) were targeted during sample collection. A peraluminous mineralogy is a first indication of the derivation from sedimentary sources (Clarke, 1981, 2019; Barbarin, 1996). Bulk-rock major element concentrations and oxygen isotopic ratios were used to confirm the origin of the studied samples (see Section 2.2). A list of all samples including location is given in Table 1.

\subsubsection{Superior Craton}

The Superior Craton forms the Archean core of the Canadian Shield and can be divided into the Western and Eastern Superior Province, which are further subdivided into 17 distinct tectonic terranes (Percival et al., 2012). (Meta-)granitoid- and greenstone-dominated terranes evolved independently from 3.7-2.75 Ga, followed by accretionary events associated with the trapping of sedimentary basins and high-temperature metamorphism, leading to the formation of a coherent Superior Craton by $2.60 \mathrm{Ga}$ (Percival et al., 2012). Peraluminous granites are widespread within the Superior Craton, and their occurrence is described in detail by others (Larbi et al., 1999; Breaks et al., 2003; Yang et al., 2019).

\subsubsection{North China Craton}

The North China Craton comprises Archean to Paleoproterozoic basement overlain by Mesoproterozoic to Cenozoic cover sequences (Zhao and Zhai, 2013). Recent publications subdivide the Precambrian basement of this region into three tectonic domains; Archean to Proterozoic Western and Eastern Blocks and a central Paleoproterozoic collisional Trans-North China Orogen (Zhao and Zhai, 2013). The Western Block comprises the Yinshan Block in the north and the Ordos Block in the south, which amalgamated at $\sim 1.95 \mathrm{Ga}$ along the Inner Mongolia Suture Zone (Santosh, 2010). The Inner Mongolia Suture Zone is dominated by a metasedimentary series associated with minor TTG gneisses, sediment-derived granites, and mafic granulites (Zhao and Zhai, 2013). The Neoarchean Yinshan Block comprises tonalite-trondhjemite-granodiorite (TTG) gneisses and minor supracrustal rocks that were metamorphosed at $\sim 2.5$ Ga (Zhao et al., 1999).

\subsubsection{Baoulé-Mossi domain, West African Craton}

The Paleoproterozoic ( 2.3-2.0 Ga) Baoulé-Mossi domain in the southern portion of the West African
Craton comprises sedimentary basins and volcanic/volcaniclastic rocks that are intruded by multiple generations of granitic rock (Parra-Avila et al., 2019, and references therein). The emplacement of felsic intrusions across the Baoulé-Mossi domain is associated with the 2.2-1.8 Eburnean Orogeny (Lompo, 2009). Based on whole rock major element and zircon oxygen isotope geochemistry a derivation from metasediments or pre-existing igneous rocks has been suggested for some of the Paleoproterozoic felsic intrusions in the Baoulé-Mossi domain (Petersson et al., 2018; Parra-Avila et al., 2019). No agreement has been reached on the tectonic model for the Paleoproterozoic evolution of this area. Proposed scenarios include plumerelated, subduction-related, and continental collisionrelated models (Parra-Avila et al., 2019, and references therein).

\subsubsection{Ukrainian Shield, East European Craton}

The Ukrainian Shield is a region of exposed Archean and Proterozoic crust within Samartia in the southwestern part of the East European Craton. The Ukrainian Shield is comprised of several tectonic blocks separated by suture zones described in detail by Claesson et al., (2006). Highgrade metamorphism and associated magmatism occurred in multiple domains of the Ukrainian Shield at $\sim 2.8$ and 2.1-2.0 Ga and may reflect an active-margin setting (Claesson et al., 2006). This episode of high-grade metamorphic and magmatic activity was associated with the reworking of older igneous and metasedimentary rocks (Claesson et al., 2006).

\subsubsection{Svecofennian domain, Baltic Shield, East European Craton}

The Svecofennian Orogeny in Finland between 1.91 and $1.87 \mathrm{Ga}$ involved accretion of island arc complexes and older crustal fragments to the Archean basement of the Karelian Craton (Väisänen et al., 2000). In southernmost Finland, $2.0-1.8$ Ga old crust was intruded by sedimentderived granites at $1.84-1.83 \mathrm{Ga}$ associated with hightemperature, low-pressure granulite facies metamorphism and migmatization (Huhma, 1986). This complex, referred to as the late Svecofennian granite-migmatite zone, includes the Sulkava, West Uusuma, and Turku areas (Ehlers et al., 1993). Granitic material is abundant in the Turku area. Mostly, these magmas occur as garnet and cordieritebearing leucosomes in migmatitic metapelites (Väisänen et al., 2000).

\subsubsection{Yavapai province}

The Yavapai province (or Colorado province) south of the Wyoming Craton comprises $1.79-1.66$ Ga volcanicplutonic suites and sediments that are interpreted to have formed in a convergent margin setting (Reed et al., 1987). These rocks experienced multiple deformational episodes associated with metamorphism and plutonism between 1.71 and $1.62 \mathrm{Ga}$ (Hoffman, 1988). The deformational episodes were followed by two pulses of magmatism at 1.50 $1.42 \mathrm{Ga}$ and 1.40-1.34 Ga (Hoffman, 1988) associated with the emplacement of peraluminous granites (Anderson and Thomas, 1985). 
Table 1

Summary of sample locations, lithologies, and mineralogy. Minerals in parentheses are accessory phases. Mineral abbreviations: Qz, quartz; Afs, alkali feldspar; Pl, plagioclase; Grt, garnet; Ms, muscovite, Bt, biotite. (1) Liebmann et al. (2021a), (2) Bucholz and Spencer (2019), and (3) Bucholz et al. (2018).

\begin{tabular}{|c|c|c|c|c|c|c|}
\hline Sample ID & Locality & Latitude & Longitude & Lithology & Mineralogy & Reference \\
\hline 17FIN01 & Turku Area, Svecofennian domain & 60.498 & 22.262 & Grt migmatite & $\mathrm{Grt}+\mathrm{Qz}+\mathrm{Afs}+\mathrm{Pl}+\mathrm{Bt}$ & This study \\
\hline 17FIN02 & Turku Area, Svecofennian domain & 60.470 & 22.368 & Grt migmatite & $\mathrm{Grt}+\mathrm{Qz}+\mathrm{Afs}+\mathrm{Pl}+\mathrm{Bt}$ & This study \\
\hline 17FIN03B & Turku Area, Svecofennian domain & 60.425 & 22.382 & Grt migmatite & $\mathrm{Grt}+\mathrm{Qz}+\mathrm{Afs}+\mathrm{Pl}+\mathrm{Bt}$ & This study \\
\hline 17FIN04A & Turku Area, Svecofennian domain & 60.461 & 22.176 & Grt migmatite & $\mathrm{Grt}+\mathrm{Qz}+\mathrm{Afs}+\mathrm{Pl}+\mathrm{Bt}$ & This study \\
\hline 17FIN05B & Turku Area, Svecofennian domain & 60.546 & 22.128 & Grt migmatite & $\mathrm{Grt}+\mathrm{Qz}+\mathrm{Afs}+\mathrm{Pl}+\mathrm{Bt}$ & This study \\
\hline 17FIN06 & Turku Area, Svecofennian domain & 60.482 & 22.018 & Grt migmatite & $\mathrm{Grt}+\mathrm{Qz}+\mathrm{Afs}+\mathrm{Pl}+\mathrm{Bt}$ & This study \\
\hline 19GH11B & Baoulé-Mossi domain, West African Craton & -1.609 & 5.140 & Bt Ms granite & $\mathrm{Ms}+\mathrm{Qz}+\mathrm{Afs}+\mathrm{Pl}+\mathrm{Bt}$ & This study \\
\hline 19GH9 & Baoulé-Mossi domain, West African Craton & -1.377 & 5.340 & Bt Ms granite & $\mathrm{Ms}+\mathrm{Qz}+\mathrm{Afs}+\mathrm{Pl}+\mathrm{Bt}$ & This study \\
\hline 19GH3 & Baoulé-Mossi domain, West African Craton & -1.156 & 5.160 & Grt granite & $\mathrm{Grt}+\mathrm{Qz}+\mathrm{Afs}+\mathrm{Pl}+\mathrm{Bt}$ & This study \\
\hline 18IM19 & $\begin{array}{l}\text { Daqingshan-Wulashan Complex, North China } \\
\text { Craton }\end{array}$ & 40.693 & 109.641 & Grt granite & $\mathrm{Grt}+\mathrm{Qz}+\mathrm{Afs}+\mathrm{Pl}+\mathrm{Bt}$ & 1 \\
\hline 18IM20 & $\begin{array}{l}\text { Daqingshan-Wulashan Complex, North China } \\
\text { Craton }\end{array}$ & 40.709 & 109.643 & Grt granitoid & $\mathrm{Grt}+\mathrm{Qz}+\mathrm{Afs}+\mathrm{Pl}+\mathrm{Bt}$ & 1 \\
\hline 18IM23D & $\begin{array}{l}\text { Daqingshan-Wulashan Complex, North China } \\
\text { Craton }\end{array}$ & 40.811 & 110.258 & Grt granite & $\mathrm{Grt}+\mathrm{Qz}+\mathrm{Afs}+\mathrm{Pl}$ & 1 \\
\hline $18 \mathrm{IM} 25 \mathrm{C}$ & Guyang Area, North China Craton & 41.182 & 109.479 & Ms Bt granite & $\mathrm{Ms}+\mathrm{Qz}+\mathrm{Afs}+\mathrm{Pl}(+\mathrm{Bt})$ & 1 \\
\hline 18IM11B & Jining Complex, North China Craton & 40.604 & 112.500 & Grt granitoid & $\mathrm{Grt}+\mathrm{Qz}+\mathrm{Afs}+\mathrm{Pl}+\mathrm{Bt}$ & 1 \\
\hline 18IM12B & Jining Complex, North China Craton & 40.839 & 112.565 & Grt quartz rich granitoid & $\mathrm{Grt}+\mathrm{Qz}+\mathrm{Afs}+\mathrm{Pl}$ & 1 \\
\hline 18IM13C & Xiwulanbulang Area, North China Craton & 41.084 & 110.924 & Grt granite & $\mathrm{Grt}+\mathrm{Qz}+\mathrm{Afs}+\mathrm{Pl}+\mathrm{Bt}(+\mathrm{Ms})$ & 1 \\
\hline 18IM15B & Xiwulanbulang Area, North China Craton & 40.994 & 110.947 & Grt granitoid & $\mathrm{Grt}+\mathrm{Qz}+\mathrm{Afs}+\mathrm{Pl}$ & 1 \\
\hline 18IM3 & Huaian Complex, North China Craton & 40.848 & 113.921 & Grt granite & $\mathrm{Grt}+\mathrm{Ms}+\mathrm{Qz}+\mathrm{Afs}+\mathrm{Pl}(+\mathrm{Bt})$ & 1 \\
\hline $15 \mathrm{~K}-2$ & Ukrainian Shield & 50.980 & 28.680 & Granite & $\mathrm{Qz}+\mathrm{Pl}+\mathrm{Bt}$ & This study \\
\hline $\mathrm{CO}-17-8$ & Silver Plume granite, Yavapai province & 39.776 & 105.780 & Bt Ms granite & $\mathrm{Ms}+\mathrm{Qz}+\mathrm{Afs}+\mathrm{Pl}+\mathrm{Bt}$ & 2 \\
\hline SP-16-2b & Shannon Lake batholith, Superior Craton & 47.661 & 92.939 & Bt Ms granite & $\mathrm{Ms}+\mathrm{Qz}+\mathrm{Afs}+\mathrm{Pl}+\mathrm{Bt}$ & 3 \\
\hline SP-16-20a & Ghost Lake batholith, Superior Craton & 49.815 & 93.020 & Bt Ms granite & $\mathrm{Ms}+\mathrm{Qz}+\mathrm{Afs}+\mathrm{Pl}+\mathrm{Bt}$ & 3 \\
\hline SP-16-34 & Ghost Lake batholith, Superior Craton & 49.848 & 92.694 & Bt Ms Grt granite & $\mathrm{Ms}+\mathrm{Qz}+\mathrm{Grt}+\mathrm{Afs}+\mathrm{Pl}+\mathrm{Bt}$ & 3 \\
\hline SP-17-43 & Wenasaga Lake batholith, Superior Craton & 50.741 & 93.209 & Bt Ms Grt granite & $\mathrm{Ms}+\mathrm{Qz}+\mathrm{Grt}+\mathrm{Afs}+\mathrm{Pl}+\mathrm{Bt}$ & This study \\
\hline SP-17-33 & Medicine Lake stock, Superior Craton & 50.284 & 94.495 & Bt Grt granite & $\mathrm{Grt}+\mathrm{Bt}+\mathrm{Qz}+\mathrm{Afs}+\mathrm{Pl}$ & This study \\
\hline SP-17-38 & Medicine Lake stock, Superior Craton & 49.863 & 93.771 & Ms Grt granite & $\mathrm{Grt}+\mathrm{Ms}+\mathrm{Qz}+\mathrm{Afs}+\mathrm{Pl}$ & This study \\
\hline SP-17-82 & Allison Lake batholith, Superior Craton & 51.200 & 92.383 & Ms Grt granite & $\mathrm{Grt}+\mathrm{Ms}+\mathrm{Qz}+\mathrm{Afs}+\mathrm{Pl}$ & 2 \\
\hline SP-17-71 & Allison Lake batholith, Superior Craton & 50.994 & 92.328 & Ms Grt granite & $\mathrm{Grt}+\mathrm{Ms}+\mathrm{Qz}+\mathrm{Afs}+\mathrm{Pl}$ & 2 \\
\hline SP-17-13 & Quetico Belt, Superior Craton & 48.906 & 89.213 & Bt Grt granite & $\mathrm{Grt}+\mathrm{Qz}+\mathrm{Afs}+\mathrm{Pl}+\mathrm{Bt}$ & This study \\
\hline SP-17-50 & Sharpe Lake batholith, Superior Craton & 50.847 & 92.105 & Bt Ms Grt granite & $\mathrm{Grt}+\mathrm{Ms}+\mathrm{Qz}+\mathrm{Afs}+\mathrm{Pl}+\mathrm{Bt}$ & This study \\
\hline
\end{tabular}




\subsection{Methodology}

Samples were prepared by trimming off weathered surfaces using a rock saw. Melanosome was removed from migmatite samples. The remaining material was washed with water and crushed. A $\sim 10 \mathrm{~g}$ aliquot per sample was powdered using a tungsten carbide ring mill for bulk-rock geochemistry. Zircon, pyrite, and garnet crystals were extracted using standard separation techniques. Handpicked zircon and pyrite crystals were mounted in epoxy resin and polished to approximately half grain thickness to expose an interior cross-section through the individual crystals. To reveal internal growth structures, CL images of zircon grains were taken prior to SIMS analysis. SIMS $\mathrm{U}-\mathrm{Pb}$ and oxygen isotope analyses were located on the same zircon growth zone (Supplementary Fig. A2). Magmatic rims of zircon grains were targeted for SIMS analyses to avoid inherited older growth zones. SIMS U-Pb analysis was conducted subsequent to SIMS oxygen isotope analysis. Backscatter electron (BSE) images and energy dispersive X-ray analysis (EDX) of pyrite grains were obtained prior to SIMS analysis. Field Emission Scanning Electron Microscope (FESEM) element maps and BSE images of garnet grains were obtained using a Tescan Integrated Mineral Analyzer (TIMA). In addition, this study reports legacy zircon $\mathrm{U}-\mathrm{Pb}$ and whole-rock major element data for one sample $(15 \mathrm{~K}-2)$ that were acquired using laser ablation inductively coupled plasma mass spectrometry (LAICPMS) and solution ICPMS, respectively. A summary of the methodology is provided below. See Appendix for a full description of the methods.

\subsubsection{SIMS zircon oxygen and pyrite sulfur isotope ratios}

In situ oxygen and sulfur isotope analyses were conducted on a CAMECA IMS 1280 secondary ion mass spectrometer (SIMS) at the Centre for Microscopy, Characterisation, and Analysis (CMCA) at the University of Western Australia and at the Guangzhou Institute of Geochemistry (GIG), Chinese Academy of Sciences, China. Oxygen and sulfur isotope compositions are reported in the conventional delta notation; expressed as $\delta^{18} \mathrm{O}$ and $\delta^{3 \mathrm{x}} \mathrm{S}$, respectively. The delta notation reflects the permil deviation in the isotope ratio of the sample $\left({ }^{18} \mathrm{O} /{ }^{16} \mathrm{O},{ }^{34} \mathrm{~S} /{ }^{32} \mathrm{~S}\right.$, and ${ }^{33} \mathrm{~S} /{ }^{32} \mathrm{~S}$ in this case) relative to a reference material. Reference materials are standard mean ocean water (VSMOW) (Baertschi, 1976) for $\delta^{18} \mathrm{O}$, and the Cañon Diabolo Troilite (VCDT) (Ding et al., 2001) for $\delta^{34} \mathrm{~S}$ and $\delta^{33} \mathrm{~S}$. The triple sulfur isotopic composition of pyrite is expressed as $\Delta^{33} \mathrm{~S}$, defined as $\delta^{33} \mathrm{~S}-1000\left(\left(1+\delta^{34} \mathrm{~S} / 1000\right)^{0.515}-1\right)$.

For zircon oxygen isotope analysis, the ${ }^{18} \mathrm{O}$ and ${ }^{16} \mathrm{O}$ ions were detected simultaneously by two faraday cups. Instrumental mass fractionation and drift were determined through repetitive analyses of zircon standard 91500 $\left(\delta^{18} \mathrm{O}=9.9 \pm 0.6 \%\right.$ ) (Wiedenbeck et al., 2004). Zircon reference materials Temora-2 $\left(\delta^{18} \mathrm{O}=8.2 \pm 0.03 \%\right.$ ) (Black et al., 2004), and Penglai $\left(\delta^{18} \mathrm{O}=5.31 \pm 0.1 \%\right.$ ) (Li et al., 2010) were used as a secondary reference to monitor the quality of the applied corrections. The analysis of the secondary standard Temora- 2 yielded $\delta^{18} \mathrm{O}$ of $8.0 \pm 0.5 \%$, and $7.8 \pm 0.4 \% \circ(2 \sigma)$ in accordance with the accepted value (but see Schmitt et al. (2019) for a discussion of oxygen isotopic heterogeneity in different batches of Temora-2). The analysis of the secondary standard Penglai yielded $\delta^{18} \mathrm{O}$ of $5.0 \pm 0.3 \%$ o $(2 \sigma)$ in accordance with the accepted value. Repeat analyses of the primary standard indicate a repeatability of $\leq 0.2 \%$ ( $1 \sigma)$ for all runs. To ensure that the oxygen isotope values reflect a primary signature, the zircon $\mathrm{OH}$ content, an indicator of secondary alteration (Pidgeon et al., 2017; Liebmann et al., 2021b) was determined qualitatively as compared to reference zircon 91500 (Supplementary Fig. A7) for all but six samples.

For pyrite sulfur isotope analysis, the ${ }^{34} \mathrm{~S},{ }^{33} \mathrm{~S}$, and ${ }^{32} \mathrm{~S}$ ions were detected simultaneously by three faraday cups. Instrumental mass fractionation and drift were determined through repeated analyses of pyrite standard Sierra $\left(\delta^{34} \mathrm{~S}=2.17 \pm 0.28 \%\right.$ o $\Delta^{33} \mathrm{~S}=-0.02 \pm 0.01 \%$ ) (LaFlamme et al., 2016). Pyrite standards Ruttan $\left(\delta^{34} \mathrm{~S}=1.2 \pm 0.35 \%\right.$, $\Delta^{33} \mathrm{~S}=0 \pm 0.22 \%$ ) (Crowe and Vaughan, 1996) and Balmat $\left(\delta^{34} \mathrm{~S}=16.02 \pm 1.18 \%\right.$ o, $\Delta^{33} \mathrm{~S}=0 \pm 0.23 \%$ ) (Whitehouse, 2013) were used as secondary standards to monitor the quality of the applied corrections. The analysis of Ruttan pyrite yielded $\delta^{34} \mathrm{~S}$ of $1.2 \pm 0.3 \%$, and $\Delta^{33} \mathrm{~S}$ of $-0.01 \pm 0.08 \%$; the analysis of Balmat pyrite yielded $\delta^{34} \mathrm{~S}$ of $16.3 \pm 0.2 \%$, and $\Delta^{33} \mathrm{~S}$ of $-0.03 \pm 0.08 \%(2 \sigma)$ in accordance with the accepted values. Repeat analyses of the primary standard indicate a repeatability of $\leq 0.15 \% \circ(1 \sigma)$ for $\delta^{34} S$ and $\leq 0.04 \%$ ( $1 \sigma)$ for $\Delta^{33} \mathrm{~S}$ for all runs (Supplementary Table A4).

Oxygen and sulfur isotope measurement results and field centering values of reference materials are given in Supplementary Fig. A7, and Supplementary Tables A3 and A4. Images of representative zircon and pyrite grains are given in Supplementary Figs. A2 and A3. Delta values of each sample are reported as weighted means (weighted based on an error of single spot analysis) with $2 \sigma$ errors (i.e. 2 standard deviations) unless stated otherwise.

\subsubsection{Laser fluorination oxygen isotope geochemistry}

Garnet grains were handpicked under a binocular to ensure they were free of inclusions and alteration. Approximately $1.6-1.8 \mathrm{mg}$ of garnet was used per analysis. Laser fluorination oxygen isotope analysis was conducted at the California Institute of Technology using a $\mathrm{CO}_{2}$ laser with $\mathrm{BrF}_{5}$ as fluorinating agent following the procedure described by (Sharp, 1990; Valley et al., 1995). All samples were analyzed in duplicate and yielded $\delta^{18} \mathrm{O}$ within $0.01-$ $0.36 \%$ of the replicate for each sample. Six to seven measurements per analytical session of Gore mountain garnet (UWG-2) (Valley et al., 1995) were interspersed with measurements of the unknowns. The analyses of UWG-2 indicate a precision of $\leq 0.07 \%$ ( $1 \sigma)$ for all runs. For all but one analysed aliquot oxygen yields were close to the predicted yields $(92-98 \%)$ indicating quantitative fluorination. One aliquot had a lower than predicted oxygen yield $(80 \%)$ due to single garnet grains jumping ot of the sample holder during lasing, but reproduced the $\delta^{18} \mathrm{O}$ value of the duplicate within $0.09 \%$ (Supplementary Table D1). Delta values are reported as weighted means with $2 \sigma$ errors unless stated otherwise. Garnet of all samples is almandine-rich with varying minor spessartine components and occurs as euhedral to subhedral grains (Supplementary Figs. A5 and A6). 


\subsubsection{SIMS zircon U-Pb geochronology}

For eight samples of this study, zircon $\mathrm{U}-\mathrm{Pb}$ ages were obtained using an A.S.I. SHRIMP II sensitive highresolution ion microprobe at the John de Laeter Centre, Curtin University, Western Australia. Operating procedures are described in detail by Wingate and Kirkland (2015). Zircon reference materials Temora-2 (417 $\pm 2 \mathrm{Ma}$, $130 \pm 21 \mathrm{U}$ ppm; Black et al., 2004), 91500 (1065 $\pm 1 \mathrm{Ma}, 81 \pm 5 \mathrm{U}$ ppm; Wiedenbeck et al., 2004), and OG1 (3465 $\pm 0.6 \mathrm{Ma}, 163 \pm 48 \mathrm{U}$ ppm; Stern et al., 2009) were used for U-Pb standardization, U concentration, and $\mathrm{Pb}-\mathrm{Pb}$ referencing, respectively. Secondary reference material OG1 yielded weighted mean ${ }^{207} \mathrm{~Pb} /{ }^{206} \mathrm{~Pb}$ * ages of $3452 \pm 35 \mathrm{Ma}(\mathrm{MSWD}=0.6 ; \mathrm{n}=4)$, and $3470 \pm 13 \mathrm{Ma}(\mathrm{MSWD}=0.47 ; \mathrm{n}=6)$; and 91500 yielded a ${ }^{238} \mathrm{U}^{206} \mathrm{~Pb}^{*}$ age of $1078 \pm 31 \mathrm{Ma}(\mathrm{MSWD}=0.68$, $\mathrm{n}=5$ ) within uncertainty of the accepted values. Details of calibration and instrumental uncertainties can be found in Supplementary Table A1.

Raw data were reduced using the Microsoft Excel add-ins SQUID 2.50 and Isoplot 3.75 with the decay constants of Steiger and Jäger (1977). Measured compositions were corrected for the presence of common $\mathrm{Pb}$ using measured ${ }^{204} \mathrm{~Pb} /{ }^{206} \mathrm{~Pb}$ and the contemporaneous $\mathrm{Pb}$ isotopic composition determined according to the terrestrial $\mathrm{Pb}$ model of Stacey and Kramers (1975). Calculated mean ages are quoted in the text at the $2 \sigma$ level (unless stated otherwise) and include propagated internal and external uncertainty components. $\mathrm{No}{ }^{207} \mathrm{~Pb} /{ }^{206} \mathrm{~Pb}$ fractionation correction was deemed necessary as OG1 yielded weighted mean ${ }^{207} \mathrm{~Pb} /{ }^{206} \mathrm{~Pb}^{*}$ ages of $3452 \pm 35 \mathrm{Ma}$ (MSWD $=0.6 ; \mathrm{n}=4$ ), and $3470 \pm 13 \mathrm{Ma}(\mathrm{MSWD}=0.47 ; \mathrm{n}=6)$ within uncertainty of the accepted value.

\subsubsection{LA ICP-MS zircon $U-P b$ geochronology}

For one sample of this study (sample $15 \mathrm{~K}-2$ ) U-Pb isotopic data were collected by laser ablation inductively coupled plasma mass spectrometry (LA ICP-MS) at the GeoHistory Facility, John de Laeter Centre, Curtin University. Zircon was ablated using a Resonetics RESOlution M50A-LR system, incorporating a COMPex 102-193 nm excimer UV laser coupled to an Agilent 8900 QQQ mass spectrometer. Zircon standard OG1 (3465 $\pm 0.6 \mathrm{Ma})$ (Stern et al., 2009) was used as the primary reference material. Secondary zircon standards yielded weighted mean ages within uncertainty of their accepted values (Supplementary Table A2).

\subsubsection{XRF and ICPMS bulk-rock geochemistry}

Bulk-rock major and minor element concentrations of 12 samples of this study were determined using a Panalytical Zetium $4 \mathrm{~kW}$ X-ray fluorescence spectrometer (XRF) at the California Institute of Technology, USA. Full analytical methods and uncertainties are given in Bucholz and Spencer (2019). For one sample (15K-2) bulk-rock major element concentrations were determined in solution by ICP-MS analysis at Bureau Veritas Minerals, Canada.

\section{RESULTS}

\subsection{Mineralogy and bulk-rock geochemistry}

Samples include granitoids comprised of quartz + alkali feldspar + plagioclase \pm biotite in varying proportions, and contain one or more peraluminous indicator minerals, such as garnet or muscovite. The samples for which bulk-rock geochemical data is available are strongly peraluminous with $\mathrm{A} / \mathrm{CNK}$ values of $\geq 1.1$ (defined as molecular $\mathrm{Al} /[\mathrm{C}$ $\mathrm{a}+\mathrm{Na}+\mathrm{K}]$; Table 2). The mineralogy of all samples is summarized in Table 1 and thin section photomicrographs can be found in Supplementary Fig. A4. Bulk-rock major element concentrations are given in Table 2.

\subsection{Geochronology}

Magmatic crystallization ages of the 30 sedimentderived granitoids in this study are Neoarchean to Mesoproterozoic, ranging from $2664 \pm 45 \mathrm{Ma}$ to $1447 \pm 50 \mathrm{Ma}$. For nine of these samples the magmatic crystallization age was determined in this study (as zircon concordia, upper intercept, or weighted mean ${ }^{207} \mathrm{~Pb}^{*} /{ }^{206}$ $\mathrm{Pb}^{*}$ ages). For nine samples zircon U-Pb SIMS ages were determined in previous studies (Liebmann et al., 2021a). For the remaining 12 samples for which no or only metamict zircon was extracted, preferred ages use robust published dates from the same batholith or are estimates based on the age of proximal magmatism. A detailed description of the geochronology is given in Appendix; a summary is given in Table 3. Single-spot zircon U-Pb results can be found in Supplementary Table B1.

\subsection{Zircon and garnet oxygen isotope geochemistry}

Twenty-six out of 28 granitoids yield zircon $\delta^{18} \mathrm{O}$ values ranging from $6.9 \pm 0.9 \%$ to $11.4 \pm 1.0 \%$. Two samples (19GH9 and 19GH11B) show distinctly lower zircon $\delta^{18} \mathrm{O}$ values of $4.9 \pm 0.8 \%$ and $5.3 \pm 0.8 \%$. Garnet $\delta^{18} \mathrm{O}$ values range from $7.1 \pm 0.1 \%$ o to $11.5 \pm 0.1 \%$. On average $\delta^{18} \mathrm{O}$ values increase post-2.3 Ga; from $7.2 \%$ to $9.9 \%$ in zircon, from $7.2 \%$ to $10.2 \%$ in garnet, and from $7.2 \%$ to $10.0 \%$ combining the data of both zircon and garnet (Fig. 2). Note that samples 19GH9 and 19GH11B with distinct zircon $\delta^{18} \mathrm{O}$ values are excluded from these averages. Including these two samples yields post-2.3 Ga averages $\delta^{18} \mathrm{O}$ values of $9.1 \%$ (in zircon) and $9.3 \%$ (combining zircon and garnet). Equilibrium fractionation of oxygen isotopes between zircon and almandine-rich garnet is small at temperatures typical for granitoid melts $\left(<0.1 \%\right.$ at temperatures $>650^{\circ}$ C) (Valley et al., 2003). The garnet-zircon pairs of all samples indicate oxygen isotopic equilibrium (Fig. 1). Two samples (17FIN02 and 17FIN04A) yield heterogeneous single spot zircon $\delta^{18} \mathrm{O}$ values $(2 \sigma>3 \%)$ and are interpreted to reflect secondary signatures related to metamictization (Pidgeon et al., 2017; Liebmann et al., 2021b). This is further supported by CL images revealing that some areas in some zircon grains are affected by metamictization (Supplementary Fig. A2). Therefore, the oxygen isotopic 
Table 2

Bulk rock major element concentrations. The aluminum saturation index $(\mathrm{A} / \mathrm{CNK})$ is calculated as molecular $\mathrm{Al} /(\mathrm{Ca}+\mathrm{Na}+\mathrm{K})$. $(1)$ Liebmann et al. (2021a), (2) Bucholz et al. (2018), (3) Bucholz and Spencer (2019).

\begin{tabular}{|c|c|c|c|c|c|c|c|c|c|c|c|c|c|c|}
\hline \multirow[t]{2}{*}{ Sample ID } & \multicolumn{12}{|c|}{ Major element concentrations (reported as oxide wt \%) } & \multirow[b]{2}{*}{$\mathrm{A} / \mathrm{CNK}$} & \multirow[b]{2}{*}{ Reference } \\
\hline & $\mathrm{SiO}_{2}$ & $\mathrm{TiO}_{2}$ & $\mathrm{Al}_{2} \mathrm{O}_{3}$ & $\mathrm{Fe}_{2} \mathrm{O}_{3}$ & $\mathrm{MgO}$ & $\mathrm{CaO}$ & $\mathrm{Na}_{2} \mathrm{O}$ & $\mathrm{K}_{2} \mathrm{O}$ & $\mathrm{P}_{2} \mathrm{O}_{5}$ & $\mathrm{MnO}$ & LOI & Total & & \\
\hline 19GH11B & 73.78 & 0.08 & 14.74 & 0.55 & 0.15 & 1.25 & 3.39 & 5.63 & 0.01 & 0.01 & 0.22 & 99.81 & 1.1 & This study \\
\hline 19GH9 & 73.23 & 0.11 & 15.67 & 1.06 & 0.28 & 2.91 & 5.02 & 1.14 & 0.03 & 0.02 & 0.63 & 100.09 & 1.1 & This study \\
\hline 19GH3 & 73.16 & 0.05 & 16.96 & 0.33 & 0.14 & 0.91 & 4.36 & 2.34 & 0.08 & 0.01 & 1.31 & 99.64 & 1.5 & This study \\
\hline 17FIN01 & 74.00 & 0.04 & 13.38 & 2.13 & 0.28 & 0.26 & 2.05 & 7.40 & 0.11 & 0.02 & 0.58 & 100.26 & 1.1 & This study \\
\hline 17FIN02 & 61.87 & 0.85 & 17.24 & 7.95 & 2.94 & 1.18 & 2.45 & 3.84 & 0.06 & 0.03 & 1.41 & 99.81 & 1.7 & This study \\
\hline 17FIN04A & 71.01 & 0.23 & 14.58 & 3.56 & 0.95 & 1.62 & 3.02 & 4.40 & 0.08 & 0.07 & 0.49 & 100.01 & 1.2 & This study \\
\hline 17FIN05B & 56.62 & 0.89 & 18.71 & 8.63 & 3.91 & 1.42 & 2.63 & 5.86 & 0.08 & 0.04 & 1.24 & 100.02 & 1.4 & This study \\
\hline 17FIN06A & 64.84 & 0.66 & 15.99 & 6.92 & 2.21 & 1.62 & 2.92 & 3.45 & 0.07 & 0.05 & 1.16 & 99.89 & 1.4 & This study \\
\hline 17FIN06B & 70.66 & 0.06 & 15.00 & 3.88 & 0.72 & 1.47 & 3.14 & 4.28 & 0.10 & 0.04 & 0.71 & 100.06 & 1.2 & This study \\
\hline 18IM19 & 72.13 & 0.31 & 14.05 & 3.51 & 1.41 & 1.27 & 2.49 & 3.68 & 0.06 & 0.05 & 0.73 & 99.69 & 1.4 & This study \\
\hline $15 \mathrm{~K}-2$ & 62.29 & 0.57 & 17.40 & 5.97 & 1.76 & 3.23 & 5.15 & 2.10 & 0.33 & 0.06 & 0.90 & 99.81 & 1.1 & This study \\
\hline 18IM11B & 61.93 & 1.06 & 18.04 & 6.58 & 2.18 & 2.88 & 2.80 & 3.58 & 0.07 & 0.06 & 0.22 & 99.38 & 1.3 & 1 \\
\hline 18IM13C & 70.74 & 0.33 & 14.84 & 3.06 & 0.87 & 3.04 & 3.29 & 1.73 & 0.10 & 0.01 & 1.00 & 99.01 & 1.2 & 1 \\
\hline 18IM15B & 65.23 & 0.58 & 15.48 & 7.01 & 2.12 & 3.52 & 2.84 & 0.96 & 0.09 & 0.09 & 1.34 & 99.25 & 1.3 & 1 \\
\hline 18IM19 & 72.13 & 0.31 & 14.05 & 3.51 & 1.41 & 1.27 & 2.49 & 3.68 & 0.06 & 0.05 & 0.73 & 99.69 & 1.4 & 1 \\
\hline 18IM20 & 63.52 & 0.26 & 17.78 & 6.13 & 1.81 & 2.63 & 3.50 & 3.05 & 0.07 & 0.07 & 0.85 & 99.69 & 1.3 & 1 \\
\hline 18IM23D & 71.76 & 0.11 & 14.05 & 2.83 & 0.79 & 0.60 & 2.01 & 6.51 & 0.12 & 0.04 & 0.50 & 99.32 & 1.2 & 1 \\
\hline 18IM25C & 74.42 & 0.06 & 13.17 & 0.95 & 0.17 & 0.95 & 2.71 & 5.80 & 0.02 & 0.00 & 0.89 & 99.15 & 1.1 & 1 \\
\hline 18IM3 & 77.57 & 0.37 & 10.88 & 3.01 & 0.87 & 1.03 & 2.23 & 2.72 & 0.05 & 0.05 & 0.68 & 99.45 & 1.3 & 1 \\
\hline SP-16-20a & 74.14 & 0.10 & 13.97 & 0.92 & 0.27 & 0.65 & 2.70 & 6.62 & 0.12 & 0.01 & 0.35 & 99.86 & 1.1 & 2 \\
\hline SP-16-2b & 72.83 & 0.18 & 14.50 & 1.33 & 0.31 & 1.11 & 4.05 & 4.58 & 0.07 & 0.03 & 0.53 & 99.53 & 1.1 & 2 \\
\hline SP-16-34 & 75.30 & 0.08 & 14.30 & 0.73 & 0.25 & 0.84 & 2.80 & 5.00 & 0.05 & 0.02 & 0.61 & 99.97 & 1.3 & 2 \\
\hline SP-17-71 & 75.31 & 0.05 & 14.11 & 0.71 & 0.06 & 0.60 & 5.45 & 1.58 & 0.11 & 0.17 & 0.97 & 98.08 & 1.3 & 3 \\
\hline SP-17-82 & 75.45 & 0.05 & 14.27 & 0.44 & 0.01 & 0.32 & 4.85 & 3.74 & 0.02 & 0.08 & 0.74 & 99.18 & 1.2 & 3 \\
\hline $\mathrm{CO}-17-8$ & 70.54 & 0.39 & 14.37 & 2.95 & 0.49 & 1.24 & 2.56 & 5.78 & 0.28 & 0.03 & 1.25 & 99.58 & 1.3 & 3 \\
\hline
\end{tabular}

composition recorded by garnet from these two samples provides the best estimate of their parental magma $\delta^{18} \mathrm{O}$. Data tables with single spot $\mathrm{O}$ isotopic data are given in Supplementary Table D1, a summary of weighted means is given in Table 3 .

\subsection{Sulfur isotope geochemistry}

Pyrite grains are euhedral to sub-euhedral, with homogenous BSE intensity, and largely free of inclusions and intergrown phases. Images of representative pyrite grains are provided in Supplementary Figs. A3 and A8. Single spot pyrite $\delta^{34} \mathrm{~S}$ and $\Delta^{33} \mathrm{~S}$ values cluster tightly around discrete values for each sample, and seemingly define single populations (Fig. 2). No sulfur isotopic intra-grain heterogeneity is observed. The weighted mean pyrite $\delta^{34} \mathrm{~S}$ values range from $-13.3 \pm 0.9 \%$ to $9.7 \pm 1.0 \%$ but are mostly (11 out of 13 samples) between $-4 \%$ and $4 \%$. Four samples contain pyrite with non-zero $\Delta^{33} \mathrm{~S}$ values (Fig. 2). These samples include three $\sim 2.7 \mathrm{Ga}$ granites from the Superior province that exhibit positive $\Delta^{33} \mathrm{~S}$ values of $0.13 \pm 0.06$ $\%$ to $0.18 \pm 0.05 \%$ and a $\sim 2.5 \mathrm{Ga}$ granite from the North China Craton with a negative $\Delta^{33} \mathrm{~S}$ value of $-0.29 \pm 0.12$ $\%$. Five out of 13 granitoids contain individual pyrite grains with sulfur isotope ratios distinct from the main population (i.e. outside of the $2 \sigma$ uncertainty of the weighted mean), including three out of 19 grains in sample SP-16$20 \mathrm{a}$, one out of 11 grains in sample SP-16-2b, two out of
27 grains in sample $15 \mathrm{~K}-2$, two out of 29 grains in sample $17 \mathrm{FIN} 03 \mathrm{~B}$, and one out of 12 grains in samples 19GH11B. These individual grains with distinct sulfur isotopic composition may reflect incomplete homogenization of sulfur between the melt and assimilated material or pyrite growth associated with secondary processes (despite the removal of melanosomes and weathered surfaces, if initially present, prior to mineral separation as thoroughly as possible). Single spot analyses obtained from these isotopically distinct grains are not considered further. Data tables with single spot sulfur isotopic data are given in Supplementary Table C1, a summary of weighted means is given in Table 3.

\section{DISCUSSION}

\subsection{Magmatic origin of zircon and garnet $O$ isotope ratios}

Strongly peraluminous granitoids are generally interpreted to derive from the partial melting of sedimentary sources (Shand, 1943; Chappell and White, 1992). Hence, the presence of magmatic aluminous mineral phases other than biotite and feldspars and/or $\mathrm{A} / \mathrm{CNK} \geq 1.1$ suggests that the studied granitoids were derived from the partial melting of metasedimentary protoliths (Shand, 1943; Chappell and White, 1992). Twenty-six out of 28 samples have garnet and zircon $\delta^{18} \mathrm{O}$ values that are elevated with respect to the mantle value of $5.3 \pm 0.6 \%$ ( $2 \sigma$; Page et al., 2007) as expected for melts that assimilated 
Table 3

Summary of $\mathrm{O}$ and S geochemistry, and crystallization ages. Isotopic data is given as weighted average with 2SD uncertainty. (1) Liebmann et al. (2021a).

\begin{tabular}{|c|c|c|c|c|c|c|c|c|c|c|c|}
\hline \multirow[t]{2}{*}{ Sample ID } & \multirow[t]{2}{*}{ Locality } & \multirow{2}{*}{$\frac{\mathrm{Age} \pm 2 \sigma}{\mathrm{Ma}}$} & \multicolumn{2}{|l|}{ Zircon } & \multicolumn{2}{|l|}{ Garnet } & \multicolumn{4}{|l|}{ Pyrite } & \multirow[t]{2}{*}{ Reference } \\
\hline & & & $\delta^{18} \mathrm{O}[\% o]$ & $2 \sigma$ & $\delta^{18} \mathrm{O}[\% o]$ & $2 \sigma$ & $\delta^{34} \mathrm{~S}[\% o]$ & $2 \sigma$ & $\Delta^{33} \mathrm{~S}[\% o]$ & $2 \sigma$ & \\
\hline 17FIN01 & Svecofennian domain & $1850^{(1)}$ & - & - & 10.39 & 0.20 & 1.54 & 0.99 & -0.01 & 0.08 & This study \\
\hline 17FIN02 & Svecofennian domain & $1896 \pm 26$ & 8.78 & 3.22 & 9.87 & 0.24 & -0.87 & 0.90 & -0.02 & 0.07 & This study \\
\hline 17FIN03B & Svecofennian domain & $1824 \pm 13$ & 9.32 & 1.16 & 9.48 & 0.51 & -0.09 & 0.88 & 0.01 & 0.08 & This study \\
\hline 17FIN04A & Svecofennian domain & $1850^{(1)}$ & 10.37 & 3.46 & 10.02 & 0.10 & 0.85 & 1.41 & 0.01 & 0.06 & This study \\
\hline 17FIN05B & Svecofennian domain & $1836 \pm 11$ & 10.52 & 0.77 & 10.30 & 0.11 & 1.61 & 0.55 & -0.01 & 0.06 & This study \\
\hline 17FIN06 & Svecofennian domain & $1815 \pm 16$ & 10.20 & 0.61 & 10.28 & 0.11 & 1.58 & 0.93 & -0.01 & 0.07 & This study \\
\hline 19GH11B & West African Craton & $2188 \pm 20$ & 5.34 & 0.83 & - & - & -3.71 & 1.51 & -0.04 & 0.07 & This study \\
\hline $15 \mathrm{~K}-2$ & Ukrainian Shield & $2144 \pm 28$ & 8.86 & 0.81 & - & - & 9.72 & 0.99 & -0.04 & 0.06 & This study \\
\hline $\mathrm{CO}-17-8$ & Yavapai province & $1447 \pm 50$ & 8.74 & 0.61 & - & - & 3.31 & 0.26 & -0.02 & 0.05 & This study \\
\hline SP-16-20a & Superior Craton & $2654 \pm 24$ & - & - & - & - & 0.60 & 0.56 & 0.13 & 0.06 & This study \\
\hline SP-16-2b & Superior Craton & $2664 \pm 45$ & - & - & - & - & 1.79 & 0.61 & 0.18 & 0.05 & This study \\
\hline SP-17-43 & Superior Craton & $2690^{(2)}$ & - & - & 7.06 & 0.09 & -13.33 & 0.92 & 0.16 & 0.05 & This study \\
\hline 18IM19 & North China Craton & $2478 \pm 18$ & 7.21 & 0.58 & 7.50 & 0.41 & -1.26 & 1.29 & -0.29 & 0.12 & This study, 1 \\
\hline 18IM20 & North China Craton & $2374 \pm 48$ & 7.39 & 0.70 & 7.22 & 0.05 & - & - & - & - & This study, 1 \\
\hline 18IM11B & North China Craton & $1901 \pm 17$ & 10.80 & 0.90 & 10.77 & 0.14 & - & - & - & - & This study, 1 \\
\hline $18 \mathrm{IM} 12 \mathrm{~B}$ & North China Craton & $1929 \pm 29$ & 9.74 & 1.16 & 10.05 & 0.12 & - & - & - & - & This study, 1 \\
\hline $18 \mathrm{IM} 3$ & North China Craton & $1917 \pm 70$ & 11.41 & 1.00 & 11.52 & 0.12 & - & - & - & - & This study, 1 \\
\hline $18 \mathrm{IM} 25 \mathrm{C}$ & North China Craton & $2493 \pm 28$ & 6.86 & 0.89 & - & - & - & - & - & - & This study, \\
\hline $18 \mathrm{IM} 13 \mathrm{C}$ & North China Craton & $2536 \pm 13$ & 8.12 & 0.70 & - & - & - & - & - & - & 1 \\
\hline 18IM15B & North China Craton & $2530 \pm 60$ & 8.57 & 0.42 & - & - & - & - & - & - & 1 \\
\hline 18IM23D & North China Craton & $2453 \pm 11$ & 6.31 & 0.63 & - & - & - & - & - & - & 1 \\
\hline 19GH9 & West African Craton & $2183 \pm 14$ & 4.93 & 0.82 & - & - & - & - & - & - & This study \\
\hline 19GH3 & West African Craton & $2180^{(1)}$ & - & - & 9.72 & 0.09 & - & - & - & - & This study \\
\hline SP-16-34 & Superior Craton & $2654 \pm 24$ & - & - & 7.99 & 0.10 & - & - & - & - & This study \\
\hline SP-17-33 & Superior Craton & $2650^{(1)}$ & - & - & 7.85 & 0.13 & - & - & - & - & This study \\
\hline SP-17-38 & Superior Craton & $2650^{(1)}$ & - & - & 6.93 & 0.11 & - & - & - & - & This study \\
\hline SP-17-82 & Superior Craton & $2650^{(1)}$ & - & - & 6.06 & 0.12 & - & - & - & - & This study \\
\hline SP-17-71 & Superior Craton & $2650^{(1)}$ & - & - & 6.92 & 0.09 & - & - & - & - & This study \\
\hline SP-17-13 & Superior Craton & $2660 \pm 10^{(3)}$ & - & - & 7.15 & 0.10 & - & - & - & - & This study \\
\hline SP-17-50 & Superior Craton & $2650^{(1)}$ & - & - & 7.55 & 0.09 & - & - & - & - & This study \\
\hline
\end{tabular}

(1) Expected age (see Appendix).

(2) Age from Corfu et al. (1995).

(3) Age from Percival (1989).

sedimentary material (Mattey et al., 1994; Valley, 2003). The exception are two granitoids from the West African Craton (19GH11B and 19GH9) with zircon $\delta^{18} \mathrm{O}$ values of $4.9 \pm 0.8 \%$ and $5.3 \pm 0.8 \%$ which are within the mantle range. These two samples could reflect assimilation of hydrothermally altered supracrustal rocks or assimilation of a relatively low- $\delta^{18} \mathrm{O}$ sedimentary component. Occurrences of low- $\delta{ }^{18} \mathrm{O}$ melts with a sedimentary component are rare, but have been reported in previous studies (Feeley and Sharp, 1995; Watts et al., 2019) and siliciclastic sedimentary rocks with $\delta^{18} \mathrm{O}$ values within the mantle range (e.g. tillites) have been documented in the compilations of Payne et al., (2015) and Bindeman (2020). However, peraluminous melts with $\delta^{18} \mathrm{O}$ values within the mantle range can also be produced from igneous protoliths; i.e. through highly fractionated melts (Cawthorn and Brown, 1976; Wu et al., 2003) or a melt sourced from hydrothermally altered volcanic rocks (Peck and Valley, 2000; Peck and Smith, 2005). Thus, these two samples cannot unequivocally be linked to the partial melting of sedimentary protoliths, and their oxygen and sulfur isotopic signatures are therefore not considered further in the discussion below.
Zircon and garnet tend to preserve a record of the oxygen isotope composition of their parental melt due to slow intracrystalline diffusion rates of oxygen in these minerals (Valley et al., 1994; Vielzeuf, 2005). Given the small equilibrium fractionation (smaller than the analytical uncertainty) of oxygen isotopes between almandine-rich garnet and zircon at temperatures typical for granitoid melts (Valley et al., 2003) (Fig. 1) $\delta^{18} \mathrm{O}$ values recorded by garnet and zircon in the granitoids of this study are directly comparable. Garnet in granitic rocks can have a number of origins, including magmatic, peritectic, and xenocrystic (Stevens et al., 2007; Erdmann et al., 2009; Lackey et al., 2011). The within error identical $\delta^{18} \mathrm{O}$ values of garnet-zircon pairs indicates equilibrium crystallization (Valley et al., 2003), and thus, a magmatic origin of garnet in these granitoids (Lackey et al., 2011). Garnet in samples without zircon $\delta^{18} \mathrm{O}$ data (samples 17FIN01, 19GH3, and samples from the Superior Craton) is also interpreted to be of magmatic origin based on the following observations. Entrainment of peritectic garnet is thought to be associated with increasing ferromagnesian contents (up to $9 \mathrm{wt} \% \mathrm{FeO}+\mathrm{MgO}$; Stevens et al., 2007). However, the available whole-rock 


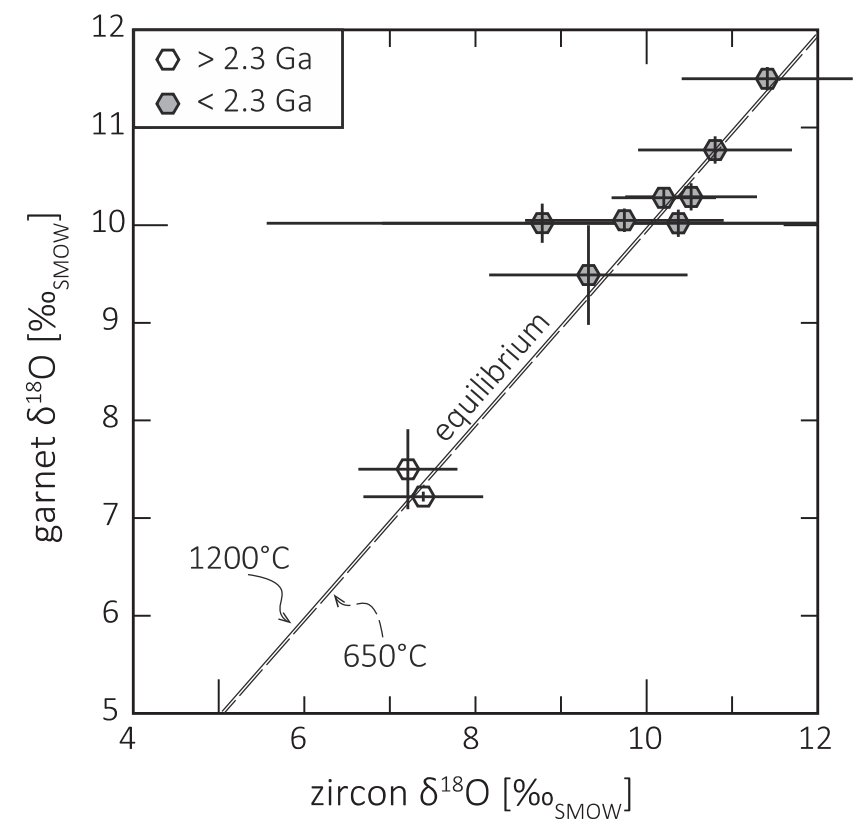

Fig. 1. Zircon $\delta^{18} \mathrm{O}$ vs garnet $\delta^{18} \mathrm{O}$ color-coded by crystallization age of sediment-derived igneous rocks. Isotherms at $650{ }^{\circ} \mathrm{C}(\mathrm{dashed}$ line) and $1200{ }^{\circ} \mathrm{C}$ (solid line) are after Valley et al. (2003). Oxygen isotope data is shown as weighted averages. Single spot results of $\mathrm{O}$ isotope analysis are given in the Appendix. Error bars are shown at $2 \sigma$ level. Note that large error bars for zircon $\delta^{18} \mathrm{O}$ are due to heterogeneity in these samples interpreted to be related to secondary processes (discussed in the text).
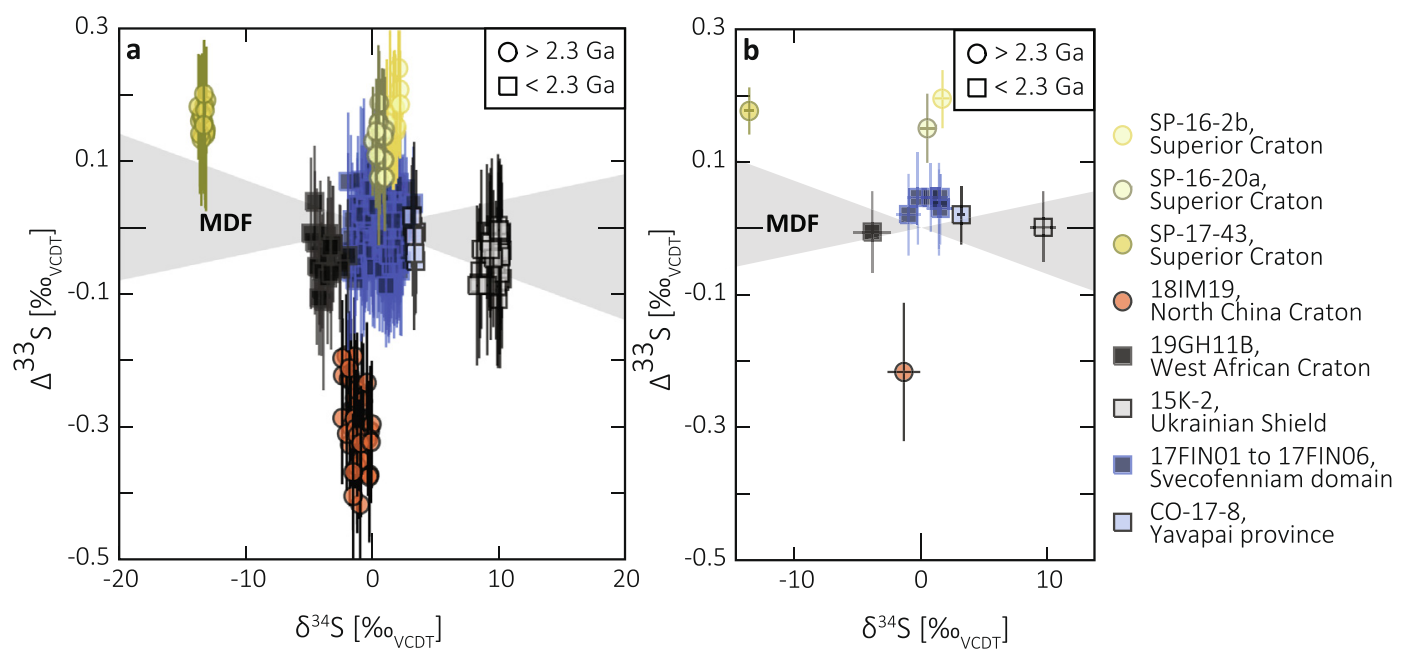

Fig. 2. Single spot (A) and weighted mean (B) $\delta^{34} \mathrm{~S}$ vs. $\Delta^{33} \mathrm{~S}$ of pyrite-bearing granitoids. Error bars are shown at $2 \sigma$ level. Grey area marks the range of $\Delta^{33} \mathrm{~S}$ values that can be produced through mass-dependent fractionation processes (LaFlamme et al., 2018b). Legend at the righthand side applied to both parts of the figure. Single spot results of sulfur isotope analysis are given in the Appendix.

major element concentrations (Table 2, see Tindle et al., 2002, for the Superior Craton batholiths) show low ferromagnesian contents in these granitoids $(\mathrm{FeO}+\mathrm{MgO} \leq 2.2$ $\mathrm{wt} \%$ ) implying no or limited entrainment of peritectic garnet (Stevens et al., 2007). Furthermore, the analysis of garnet aliquots in duplicate indicates homogenous garnet oxygen isotopic ratios in these samples with $2 \mathrm{SD}<0.2 \%$, implying that a xenocrystic origin of garnet in these samples is unlikely, as xenocrystic garnet commonly results in multiple garnet populations with distinct oxygen isotope ratio (Harris and Vogeli, 2010; Lackey et al., 2011).

\subsection{The influence of continental emergence on $\delta^{18} \mathrm{O}$ in sediment melts}

The average zircon and garnet $\delta^{18} \mathrm{O}$ values of sedimentderived melts increase $7.2 \%$ pre- $2.3 \mathrm{Ga}$ to $10.0 \%$ post$2.3 \mathrm{Ga}$ (Fig. 3) in accord with previous studies (Spencer et al., 2019; Bindeman, 2020; Liebmann et al., 2021a). The average $\delta^{18} \mathrm{O}$ value of shales increases from the early Archean to present (Payne et al., 2015; Bindeman, 2020). An increase in shale $\delta^{18} \mathrm{O}$ value can be achieved through a higher ratio of secondary (authigenic) to primary (detri- 

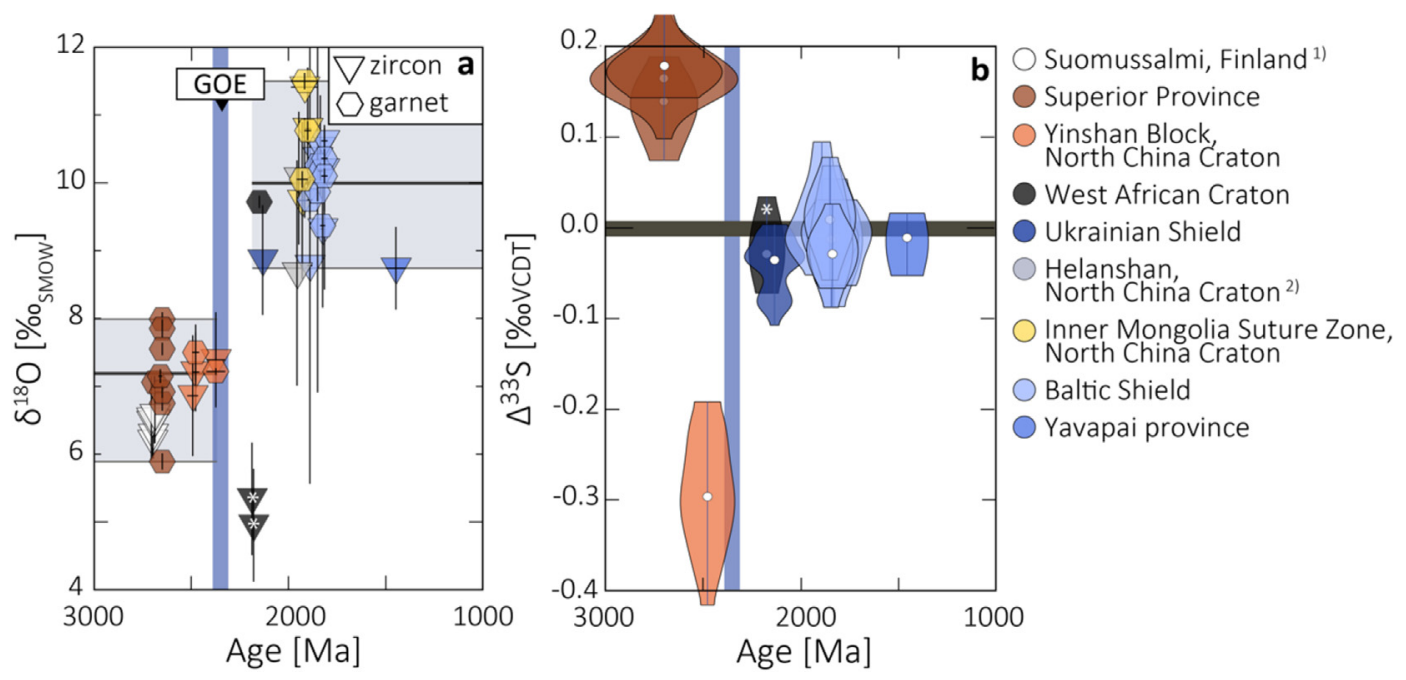

Fig. 3. Oxygen and sulfur isotopic data vs. crystallization age. Timing of atmospheric oxygenation (Luo et al., 2016) is shown as the blue bar. Legend on the right applies to both parts of the figure. (A) Zircon and garnet $\delta^{18} \mathrm{O}$ vs. granitoid crystallization ages. Oxygen isotope data is shown as weighted averages. Black bars mark average $\delta^{18} \mathrm{O}$ (as recorded by zircon and garnet) pre- and post-2.3 Ga, respectively. The two samples marked by asterisks show evidence for complex petreogeneses (see text for discussion) and have been omitted from the calculation of the $\delta^{18} \mathrm{O}$ averages. Single spot results of $\mathrm{O}$ isotope analysis are given in the Appendix. Error bars for oxygen isotope data and age are $2 \sigma$. Zircon oxygen isotope data from sediment-derived granitoids in Suomussalmi and Helanshan are from (1) Mikkola et al. (2011), and (2) Dan et al. (2014). (B) Pyrite $\Delta^{33} \mathrm{~S}$ vs. granitoids crystallization shown as violin plots; white circles mark medians. Black bar marks $\Delta^{33} \mathrm{~S}=0 \%$. The white asterisk marks a sample with complex petrogenesis (see text for discussion) that has been omitted from the interpretation.

tal) mineral components, on average lower temperatures of fluid-rock interaction during diagenesis and chemical weathering, and changes in the oxygen isotope composition of the weathering fluid (Savin and Epstein, 1970; Knauth and Lowe, 2003). A change in the triple oxygen isotope ratio in shales between 2.43 and $2.31 \mathrm{Ga}$ has been linked to a change in the oxygen isotope composition of the fluid involved in the weathering of the continents (Bindeman et al., 2018; Bindeman, 2020). It has been proposed that the timing of this change in shale triple oxygen isotope ratio marks the onset of a modern hydrological cycle associated with the emergence of continents (Bindeman et al., 2018). Furthermore, an increased subaerial land area may have facilitated high- $\delta{ }^{18} \mathrm{O}$ shale formation through enhanced chemical weathering and erosion of continents supporting clay-mineral formation (the high- $\delta^{18} \mathrm{O}$ component in shales; Hazen et al., 2013; Payne et al., 2015). Therefore, increased subaerial exposure of continents may have resulted in the formation of high- $\delta{ }^{18} \mathrm{O}$ shales that upon subsequent recycling caused an increase in zircon $\delta^{18} \mathrm{O}$ (Payne et al., 2015; Spencer et al., 2019; Bindeman, 2020). Archean continents were at least locally raised above sea level as evident from siliciclastic sediments and subaerial volcanism (e.g. Eriksson et al., 1999). However, geochemical proxies and numerical models suggest that the subaerial exposure of Archean continents was limited (Flament et al., 2013; Johnson and Wing, 2020). The widespread emergence of continents (i.e. a change from locally subaerial continents to large-scale subaerial exposure of continents) at the Archean-Proterozoic transition is supported by changes to geochemical proxies at this time, such as an increase in seawater ${ }^{87} \mathrm{Sr} /{ }^{86} \mathrm{Sr}$ (Flament et al., 2013), a decrease in shale $\Delta^{17} \mathrm{O}$ (Bindeman et al., 2018; Bindeman, 2020), as well as an increase in subaerial large igneous province volcanism (Kump and Barley, 2007).

\subsection{Origin of pyrite $S$ isotope ratios and the influence of atmospheric oxygenation}

Pyrite-bearing sediment-derived granitoids with crystallization ages $>2.3 \mathrm{Ga}$ yield non-zero $\Delta^{33} \mathrm{~S}$ values, whereas those younger than $2.3 \mathrm{Ga}$ uniformly show $\Delta^{33} \mathrm{~S}$ of $0 \%$. Previous studies demonstrated strong mass-depended fractionation of $\mathrm{S}$ isotopes in post-GOE sedimentary sulfur species (i.e. $\delta^{34} \mathrm{~S}$ ranging from $\sim-50 \%$ to $50 \%$ and $\Delta^{33} \mathrm{~S}$ of $\sim 0 \%$ ), whereas pre-GOE sedimentary sulfur species show a slightly smaller range in $\delta^{34} \mathrm{~S}$ values $(\sim-20$ to $30 \%$ ) and a large range in $\Delta^{33} \mathrm{~S}$ values ( -2 to 14\%o) (Johnston, 2011; Killingsworth et al., 2019). Furthermore, $\Delta^{33} \mathrm{~S}$ and $\delta^{34} \mathrm{~S}$ values in pre-GOE sediments and igneous rocks that assimilated sediments are overall positively correlated (Farquhar and Wing, 2003; Ono et al., 2003; Johnston, 2011; LaFlamme et al., 2018a). The granitoids of this study fall within the range of previously reported $\delta^{34} \mathrm{~S}$ and $\Delta^{33} \mathrm{~S}$ values of Archean and Proterozoic sedimentary sulfur phases. Within the comparatively restricted range of $\delta^{34} \mathrm{~S}$ and $\Delta^{33} \mathrm{~S}$ values (ranging from $-13 \%$ to $10 \%$ and $-0.3 \%$ to $0.2 \%$, respectively) no increase in range of $\delta^{34} \mathrm{~S}$ values post-GEO nor a correlation between $\delta^{34} \mathrm{~S}$ and $\Delta^{33} \mathrm{~S}$ values pre-GOE is apparent from the granitoids of this study. The magnitude of $\Delta^{33} \mathrm{~S}$ values of the $>2.3 \mathrm{Ga}$ granitoids are small $(-0.29 \%$ to $0.18 \%$ o compared to those in preGOE sedimentary rocks ( - 2\%o to 14\%o) (Johnston, 2011; Killingsworth et al., 2019). Small non-zero $\Delta^{33} S$ values can be produced through reactions controlled by S-MDF (e.g. Ono et al., 2006). The generation of non-zero 
$\Delta^{33} \mathrm{~S} \pm 1 \%$ o through MDF processes requires strong fractionation of the ${ }^{34} \mathrm{~S} /{ }^{32} \mathrm{~S}$ isotope ratio (LaFlamme et al., 2018b). Therefore, threshold $\Delta^{33} \mathrm{~S}$ values for MDF can be calculated based on $\delta^{34} \mathrm{~S}$ (LaFlamme et al., 2018b). The $\delta^{34} \mathrm{~S}$ values of the four $>2.3 \mathrm{Ga}$ granitoids correspond to threshold MDF $\Delta^{33} \mathrm{~S}$ values of $-0.053 \%$ and $0.093 \%$ for sample SP-17-43 (measured $\Delta^{33} \mathrm{~S}=0.16 \pm 0.05 \%$ ), $-0.005 \%$ and $0.009 \%$ for sample 18IM19C (measured $\Delta^{33} \mathrm{~S}=-0.29 \pm 0.12 \%$ ),$-0.013 \%$ and $0.007 \%$ or sample SP-16-2b (measured $\Delta^{33} \mathrm{~S}=0.18 \pm 0.05 \%$ ), and $-0.004 \%$ o and $0.002 \%$ for sample SP-16-20a (measured $\Delta^{33} \mathrm{~S}=0.13$ $\pm 0.06)$. Hence, the magnitude of non-zero $\Delta^{33} \mathrm{~S}$ values observed in the $>2.3 \mathrm{Ga}$ granitoids is too large to be the result of S-MDF processes alone (Fig. 2). Therefore, the $\mathrm{S}-\mathrm{MIF}$ signatures in these granitoids are interpreted to record the recycling of sedimentary sulfur species (i.e. through assimilation and partial melting of sediments) formed under the anoxic pre-GOE atmosphere. The transfer of sulfur isotope signatures from sediments into the igneous rock record has been documented in previous studies (Bekker et al., 2009; LaFlamme et al., 2018a; Bucholz et al., 2020). A previous study on an Archean sedimentderived granitic batholith and its source rocks demonstrated that during the process of metamorphism and partial melting, $\delta^{34} \mathrm{~S}$ values are fractionated from the sedimentary protolith values by at most $+2 \%$ to $+3 \%$ o and that S-MIF values are preserved (Bucholz et al., 2020). This gives us confidence that we can interpret the $S$ isotope signature of our samples in the context of the bulk sedimentary packages from which they were derived. Three of the $>2.3 \mathrm{Ga}$ granitoids of this study show positive $\Delta^{33} \mathrm{~S}$ values, one sample shows a negative $\Delta^{33} \mathrm{~S}$ value. The preGOE sedimentary record is skewed towards positive $\Delta^{33} \mathrm{~S}$ values (Johnston, 2011; Killingsworth et al., 2019). Positive $\Delta^{33} \mathrm{~S}$ anomalies are commonly found in Archean sedimentary pyrite that may have formed from reduced sulfur species (e.g. $\mathrm{S}_{8}$ aerosols) produced through photodissociation in the oxygen-poor atmosphere (Farquhar et al., 2000; Farquhar et al., 2002). Based on the dominance of negative $\Delta^{33} \mathrm{~S}$ values in Archean barites, it has been posited that oceanic sulfates (formed from oxidized sulfur species produced through photodissociation; e.g. $\mathrm{SO}_{4}$ aerosols) carry the complementary negative $\Delta^{33} \mathrm{~S}$ signatures required by isotopic mass balance (Farquhar et al., 2000). The recycling of marine sediments into the mantle may explain the 'missing' negative $\Delta^{33} \mathrm{~S}$ reservoir (Farquhar and Jackson, 2016). A negative $\Delta^{33} \mathrm{~S}$ reservoir in the mantle is supported by plume-fed hotspot lavas with negative $\Delta^{33} \mathrm{~S}$ signatures (Cabral et al., 2013; Delavault et al., 2016). However, studies that report predominantly positive or zero $\Delta^{33} \mathrm{~S}$ values in Archean oceanic sulfate, mid-ocean ridge basalts, and trapped sulfides in diamonds from the lithospheric mantle challenge this view (Farquhar et al., 2002; Paris et al., 2014; Labidi et al., 2015; Smit et al., 2019). The inconsistent sulfur isotopic budget is a yet unsolved scientific problem, and the complementary negative $\Delta^{33} \mathrm{~S}$ reservoir remains cryptic.

The low $\delta^{34} \mathrm{~S}$ value $(\sim-13 \%$ ) of pyrite in sample SP-1743 from the Wenasaga Lake batholith, Superior province, could derive from the contribution of organic sulfur.
Microbial sulfate reduction commonly produces sulfides that are strongly depleted in the heavy ${ }^{34} \mathrm{~S}$ isotope (Johnston et al., 2007). The S-MIF signature in this sample $\left(\Delta^{33} \mathrm{~S}=0.16 \pm 0.04 \%\right.$ ) indicates atmospheric influence. Therefore, the recorded sulfur isotopic composition of this sample may be the result of mixing between two reservoirs (i.e. atmospheric and microbial sulfur). A similar scenario has been suggested to be responsible for the negative $\delta^{34} \mathrm{~S}$ values and positive $\Delta^{33} \mathrm{~S}$ values of pyrite in the Archean upper Mount McRae Shale in the Hamersley Basin, Western Australia (Ono et al., 2003; Kaufman et al., 2007). Sulfide $\delta^{34} \mathrm{~S}$ values below -10\% (as observed in sample SP-1743) are exceedingly rare in pre-GOE sediments (Canfield, 2001; Johnston, 2011). This absence of strongly fractionated sulfides in pre-GOE sediments has been linked to low seawater sulfate concentration resulting in small $\mathrm{S}$ isotope fractionation during microbial sulfate reduction (Canfield, 2001). Alternatively, the low $\delta^{34} \mathrm{~S}$ value in this sample could arise during fractionation between $\mathrm{S}^{2-}$ in the melt and $\mathrm{H}_{2} \mathrm{~S}$ in a vapor phase (produced through metamorphic devolatilization) as documented for other samples from the Superior Craton (Bucholz et al., 2020). Note that at the low oxygen fugacities recorded by some pre-GOE sediment-derived granitoids (Bucholz et al., 2018) $\mathrm{H}_{2} \mathrm{~S}$ (as opposed to $\mathrm{SO}_{2}$ ) is the dominant sulfur-bearing vapor phase (Poulson and Ohmoto, 1989). While devolatilization can strongly influence $\delta^{34} \mathrm{~S}, \Delta^{33} \mathrm{~S}$ is unaffected (Bucholz et al., 2020).

\subsection{A link between continental emergence and atmospheric oxygenation?}

Sediment-derived granitoids inherit their oxygen and sulfur isotopic ratios from their sedimentary sources (Bindeman, 2020; Bucholz et al., 2020) and therefore, provide an archive of these signatures in bulk siliciclastic sediments that is relatively unaffected by secondary alteration and can be tied directly to zircon crystallization ages. The youngest sediment-derived granitoid of this study that shows S-MIF and oxygen isotopic signatures respectively implying an anoxic atmosphere and widely submerged continents (sample 18IM19) has a crystallization age of $2478 \pm 18 \mathrm{Ma}$. The oldest sample (15K-2) showing only $\mathrm{S}-\mathrm{MDF}$ and $\mathrm{O}$ isotopic signatures indicating respectively an oxygenized atmosphere and emergent continents yields a crystallization age of $2144 \pm 28 \mathrm{Ma}$. The evolution of oxygen and sulfur isotopic signatures (towards highly fractionated $\delta^{18} \mathrm{O}$ values and the disappearance of S-MIF signatures post-2.3 Ga) appear to be temporally coupled in the samples of this study. However, the data is inconclusive for the $\sim 300 \mathrm{Myr}$ interval between the youngest SMIF and the oldest S-MDF sample. The preserved rock record between 2.4 and $2.2 \mathrm{Ga}$ is sparse (Condie et al., 2009; Spencer et al., 2018) making it challenging to fill this temporal gap. The lifespan of sedimentary basins ranges from $<1$ Myr for trench basins to $>100$ Myr for intracratonic basins (Woodcock, 2004). Hence, due to the lag time between sediment deposition and partial melting, the granitoids studied here only provide minimum ages for the secular changes in the oxygen and sulfur isotopic systems in 
sediment-derived granitoids. Importantly, however, this is inconsequential for the fact that the evolution of oxygen and sulfur isotopic signatures seems to be coupled. If the evolution of sulfur and oxygen isotopic signatures in sediment-derived melts is indeed coupled, this would provide strong evidence for a temporal and potentially causal connection of the emergence of continents and atmospheric oxygenation.

Numerical models demonstrate the strong influence of subaerial continental emergence on nutrient flux (such as P) to the oceans (Hao et al., 2020). The availability of nutrients is thought to control marine primary productivity on geologic timescales (Howarth, 1988; Tyrrell, 1999; Holland, 2020). Elevated, emerged continental crust and associated enhanced erosion would increase the supply of life-essential nutrients into the ocean, increasing that available for oxyphotobacteria (Campbell and Allen, 2008; Cox et al., 2018; Hao et al., 2020). Furthermore, a shift in ocean nutrient availability from $\mathrm{P}$ to $\mathrm{Fe}$ limiting may have resulted in ecological conditions favourable for oxygenic photoautotrophs over anoxygenic photoautotrophs (Jones et al., 2015; Ozaki et al., 2019). However, marine sediments show relatively constant, low P contents until 800-700 Ma (Planavsky et al., 2010; Reinhard et al., 2017). This apparent disagreement may be explained through (1) the GOE facilitating efficient recycling of $\mathrm{P}$ through remineralization of sinking biomass limiting $\mathrm{P}$ burial in sediments (Kipp and Stüeken, 2017), (2) an adaptation of photosynthetic bacteria to low $\mathrm{P}$ availability (i.e. high $\mathrm{C} / \mathrm{R}$ ratios) inhibiting $\mathrm{P}$ burial in marine sediments (Reinhard et al., 2017; Kipp and Stüeken, 2017), (3) pre-GOE primary production was limited by continentally-derived trace metals rather than P (Scott et al., 2008; Planavsky et al., 2010). Increased erosion and sediment supply from the elevated continents would facilitate the burial of organic carbon leading to diminished $\mathrm{O}_{2}$ consumption (Campbell and Allen, 2008). The proportion of submarine to subaerial volcanism would also change, which in turn alters the redox state of volcanic gases towards more oxidizing (Kump and Barley, 2007; Gaillard et al., 2011).

\section{CONCLUDING REMARKS}

Sediment-derived granitoids provide a record of bulk siliciclastic sediment composition and demonstrate an increase in average $\delta^{18} \mathrm{O}$ and a disappearance of S-MIF signatures post- $2.3 \mathrm{Ga}$. These changes in the $\mathrm{O}$ and $\mathrm{S}$ isotopic signatures are influenced by subaerial continental exposure and atmospheric oxygen level, respectively, and change concomitantly in this sample suite. The implication is that the subaerial emergence of continents and atmospheric oxygenation were coeval and that the former could have contributed to atmospheric oxygenation by facilitating primary production and/or attenuating $\mathrm{O}_{2}$ sinks.

\section{DATA AVAILABILITY STATEMENT}

The data that support the findings of this study are provided in the Supplementary material.

\section{Declaration of Competing Interest}

The authors declare that they have no known competing financial interests or personal relationships that could have appeared to influence the work reported in this paper.

\section{ACKNOWLEDGEMENTS}

We thank Crystal LaFlamme and two anonymous reviewers for their constructive comments, and Shuhei Ono for editorial handling. U-Pb geochronology analytical work at the John de Laeter Centre, Western Australia was enabled by NCRIS via AuScope. Oxygen and sulfur isotope analytical work at the Guangzhou Institute of Geochemistry was supported by the open fund from the State Key Laboratory of Isotope Geochemistry, GIGCAS (SKLabIG-KF-18-04). The authors acknowledge the facilities, and the scientific and technical assistance of Microscopy Australia at the Centre for Microscopy, Characterisation \& Analysis, The University of Western Australia, a facility funded by the University, State and Commonwealth Governments.

\section{AUTHOR CONTRIBUTIONS}

JL, CJS, CLK, CEB designed the research or contributed to designing the research. JL, CJS, CEB, LS collected the samples. JL, CLK, CEB, XPX, LM, NK carried out the analyses. JL, CJS, CLK, CEB contributed to interpreting the results. JL wrote the manuscript. All authors provided comments on the manuscript.

\section{APPENDIX A. SUPPLEMENTARY MATERIAL}

Supplementary data to this article can be found online at https://doi.org/10.1016/j.gca.2021.05.045.

\section{REFERENCES}

Anderson J. L. and Thomas W. M. (1985) Proterozoic anorogenic two-mica granites: Silver Plume and St. Vrain batholiths of Colorado. Geology 13, 177.

Baertschi P. (1976) Absolute 180 content of standard mean ocean water. Earth Planet. Sci. Lett. 31, 341-344

Barbarin B. (1996) Genesis of the two main types of peraluminous granitoids. Geology 24, 295-298.

Bekker A., Barley M. E., Fiorentini M. L., Rouxel O. J., Rumble D. and Beresford S. W. (2009) Atmospheric Sulfur in Archean Komatiite-Hosted Nickel Deposits. Science (80-.) 326, 1086 1089.

Bekker A. and Holland H. D. (2012) Oxygen overshoot and recovery during the early Paleoproterozoic. Earth Planet. Sci. Lett. 317-318, 295-304.

Bindeman I. N. (2020) Triple oxygen isotopes in evolving continental crust, granites, and clastic sediments. Rev. Mineral. Geochem. 86.

Bindeman I. N., Zakharov D. O., Palandri J., Greber N. D., Dauphas N., Retallack G. J., Hofmann A., Lackey J. S., Bekker A. and Data E. (2018) Rapid emergence of subaerial landmasses and onset of a modern hydrologic cycle 2.5 billion years ago. Nature 557, 545-548. 
Black L. P., Kamo S. L., Allen C. M., Davis D. W., Aleinikoff J. N., Valley J. W., Mundil R., Campbell I. H., Korsch R. J., Williams I. S. and Foudoulis C. (2004) Improved 206Pb/238U microprobe geochronology by the monitoring of a traceelement-related matrix effect; SHRIMP, ID-TIMS, ELA-ICPMS and oxygen isotope documentation for a series of zircon standards. Chem. Geol. 205, 115-140.

Breaks F. W., Selway J. B. and Tindle A. G. (2003) Fertile peraluminous granites and related rare-element mineralization in pegmatites, Superior Province, northwest and northeast Ontario: Operation Treasure Hunt. Ontario Geological Survey, Open File Report 6099.

Bucholz C. E., Biasi J. A., Beaudry B. P. and Ono S. (2020) Sulfur isotope behavior during metamorphism and anatexis of Archean sedimentary rocks: a case study from the Ghost Lake batholith, Ontario, Canada. Earth Planet. Sci. Lett. 549.

Bucholz C. E. and Spencer C. J. (2019) Strongly peraluminous granites across the Archean-Proterozoic transition. J. Petrol. 60, 1299-1348.

Bucholz C. E., Stolper E. M., Eiler J. M. and Breaks F. W. (2018) A comparison of oxygen fugacities of strongly peraluminous granites across the Archean-Proterozoic Boundary. J. Petrol. 59, 2123-2156.

Cabral R. A., Jackson M. G., Rose-Koga E. F., Koga K. T., Whitehouse M. J., Antonelli M. A., Farquhar J., Day J. M. D. and Hauri E. H. (2013) Anomalous sulphur isotopes in plume lavas reveal deep mantle storage of Archaean crust. Nature 496, 490-493.

Campbell I. H. and Allen C. M. (2008) Formation of supercontinents linked to increases in atmospheric oxygen. Nat. Geosci. 1, 554-558.

Canfield D. E. (2001) Biogeochemistry of Sulfur Isotopes. Rev. Mineral. Geochemistry 43, 607-636.

Catling D. C., Glein C. R., Zahnle K. J. and McKay C. P. (2005) Why O 2 Is Required by Complex Life on Habitable Planets and the Concept of Planetary "Oxygenation Time". Astrobiology 5, 415-438.

Cawthorn R. G. and Brown P. A. (1976) A Model for the Formation and Crystallization of Corundum-Normative CalcAlkaline Magmas through Amphibole Fractionation. J. Geol. 84, 467-476.

Chappell B. W. and White A. J. R. (1992) I- and S-type granites in the Lachlan Fold Belt. Earth Environ Sci. Trans. R. Soc. Edinburgh 83, 1-26.

Claesson S., Bibikova E., Bogdanova S. and Skobelev V. (2006) Archaean terranes, Palaeoproterozoic reworking and accretion in the Ukrainian Shield, East European Craton. Geol Soc. London, Mem. 32, 645-654.

Clarke D. B. (1981) The mineralogy of peraluminous granites; a review. Can. Mineral. 19, 3-17.

Clarke D. B. (2019) The origins of strongly peraluminous granitoid rocks. Can. Mineral. 57, 529-550.

Condie K. C., O’Neill C. and Aster R. C. (2009) Evidence and implications for a widespread magmatic shutdown for $250 \mathrm{My}$ on Earth. Earth Planet. Sci. Lett. 282, 294-298.

Corfu F., Stott G. M. and Breaks F. W. (1995) U-Pb geoehronology and evolution of the English River Subprovince, an Archean low P-high T metasedimentary belt in the Superior Province. Tectonics 14, 1220-1233.

Cox G. M., Lyons T. W., Mitchell R. N., Hasterok D. and Gard M. (2018) Linking the rise of atmospheric oxygen to growth in the continental phosphorus inventory. Earth Planet. Sci. Lett. 489, 28-36.

Crowe D. E. and Vaughan R. G. (1996) Characterization and use of isotopically homogeneous standards for in situ laser microprobe analysis of 34 S/ 32 S ratios. Am. Mineral. 81, 187-193.
Dan W., Li X.-H., Wang Q., Wang X.-C., Liu Y. and Wyman D. A. (2014) Paleoproterozoic S-type granites in the Helanshan Complex, Khondalite Belt, North China Craton: Implications for rapid sediment recycling during slab break-off. Precambrian Res. 254, 59-72.

Delavault H., Chauvel C., Thomassot E., Devey C. W. and Dazas B. (2016) Sulfur and lead isotopic evidence of relic Archean sediments in the Pitcairn mantle plume. Proc. Natl. Acad. Sci. 113, 12952-12956.

Ding T., Valkiers S., Kipphardt H., De Bièvre P., Taylor P. D. P., Gonfiantini R. and Krouse R. (2001) Calibrated sulfur isotope abundance ratios of three IAEA sulfur isotope reference materials and V-CDT with a reassessment of the atomic weight of sulfur. Geochim. Cosmochim. Acta 65, 24332437.

Ehlers C., Lindroos A. and Selonen O. (1993) The late Svecofennian granite-migmatite zone of southern Finland-a belt of transpressive deformation and granite emplacement. Precambrian Res. 64, 295-309.

Erdmann S., Jamieson R. A. and MacDonald M. A. (2009) Evaluating the Origin of Garnet, Cordierite, and Biotite in Granitic Rocks: a Case Study from the South Mountain Batholith, Nova Scotia. J. Petrol. 50, 1477-1503.

Eriksson P. G., Mazumder R., Sarkar S., Bose P. K., Altermann W. and van der Merwe R. (1999) The 2.7-2.0 Ga volcanosedimentary record of Africa, India and Australia: evidence for global and local changes in sea level and continental freeboard. Precambrian Res. 97, 269-302.

Farquhar, Bao and Thiemens (2000) Atmospheric influence of Earth's earliest sulfur cycle. Science (New York, NY) 289, 756759.

Farquhar J. and Jackson M. (2016) Missing Archean sulfur returned from the mantle. Proc. Natl. Acad. Sci. 113(46), 12893-12895.

Farquhar J. and Wing B. A. (2003) Multiple sulfur isotopes and the evolution of the atmosphere. Earth Planet. Sci. Lett. 213, 1-13.

Farquhar J., Wing B. A., McKeegan K. D., Harris J. W., Cartigny P. and Thiemens M. H. (2002) Mass-Independent Sulfur of Inclusions in Diamond and Sulfur Recycling on Early Earth. Science (80-.) 298, 2369-2372.

Feeley T. C. and Sharp Z. D. (1995) 180160 isotope geochemistry of silicic lava flows erupted from Volcán Ollagüe, Andean Central Volcanic Zone. Earth Planet. Sci. Lett. 133, 239-254.

Fischer W. W., Hemp J. and Johnson J. E. (2016) Evolution of Oxygenic Photosynthesis. Annu. Rev. Earth Planet. Sci. 44, 647-683.

Flament N., Coltice N. and Rey P. F. (2013) The evolution of the $87 \mathrm{Sr} / 86 \mathrm{Sr}$ of marine carbonates does not constrain continental growth. Precambrian Res. 229, 177-188.

Gaillard F., Scaillet B. and Arndt N. T. (2011) Atmospheric oxygenation caused by a change in volcanic degassing pressure. Nature 478, 229-232.

Gumsley A. P., Chamberlain K. R., Bleeker W., Söderlund U., de Kock M. O., Larsson E. R. and Bekker A. (2017) Timing and tempo of the Great Oxidation Event. Proc. Natl. Acad. Sci. 114, 1811-1816.

Guo Q., Strauss H., Kaufman A. J., Schröder S., Gutzmer J., Wing B., Baker M. A., Bekker A., Jin Q., Kim S. T. and Farquhar J. (2009) Reconstructing Earth's surface oxidation across the Archean-Proterozoic transition. Geology 37, 399402.

Hao J., Knoll A. H., Huang F., Hazen R. M. and Daniel I. (2020) Cycling phosphorus on the Archean Earth: Part I. Continental weathering and riverine transport of phosphorus. Geochim. Cosmochim. Acta 273, 70-84. 
Harada M., Tajika E. and Sekine Y. (2015) Transition to an oxygen-rich atmosphere with an extensive overshoot triggered by the Paleoproterozoic snowball Earth. Earth Planet. Sci. Lett. 419, 178-186.

Harris C. and Vogeli J. (2010) Oxygen isotope composition of garnet in the peninsula granite, cape granite suite, South Africa: Constraints on melting and emplacement mechanisms. S. Afr.J. Geol. 113, 401-412.

Hazen R. M., Sverjensky D. A., Azzolini D., Bish D. L., Elmore S. C., Hinnov L. and Milliken R. E. (2013) Clay mineral evolution. Am. Mineral. 98, 2007-2029.

Hoffman P. F. (1988) United Plates of America, The Birth of a Craton: Early Proterozoic Assembly and Growth of Laurentia. Annu. Rev. Earth Planet. Sci. 16, 543-603.

Holland H. D. (2020) The Chemical Evolution of the Atmosphere and Oceans. Princeton University Press.

Holland H. D. (2002) Volcanic gases, black smokers, and the great oxidation event. Geochim. Cosmochim. Acta 66, 3811-3826.

Howarth R. W. (1988) Nutrient Limitation of Net Primary Production in Marine Ecosystems. Annu. Rev. Ecol. Syst. 19, 89-110.

Huhma H. (1986) Sm-Nd, U-Pb, and Pb-Pb isotopic evidence for the origin of the early Proterozoic Svecokarelian crist in Finland Bulletin 3. Geological Survey of Finland.

Johnson B. W. and Wing B. A. (2020) Limited Archaean continental emergence reflected in an early Archaean 180enriched ocean. Nat. Geosci. 13, 243-248.

Johnston D. T. (2011) Multiple sulfur isotopes and the evolution of Earth's surface sulfur cycle. Earth-Science Rev. 106, 161183.

Johnston D. T., Farquhar J. and Canfield D. E. (2007) Sulfur isotope insights into microbial sulfate reduction: When microbes meet models. Geochim. Cosmochim. Acta 71, 39293947.

Jones C., Nomosatryo S., Crowe S. A., Bjerrum C. J. and Canfield D. E. (2015) Iron oxides, divalent cations, silica, and the early earth phosphorus crisis. Geology 43, 135-138.

Kaufman A. J., Johnston D. T., Farquhar J., Masterson A. L., Lyons T. W., Bates S., Anbar A. D., Arnold G. L., Garvin J. and Buick R. (2007) Late Archean Biospheric Oxygenation and Atmospheric Evolution. Science (80-.) 317, 1900-1903.

Killingsworth B. A., Sansjofre P., Philippot P., Cartigny P., Thomazo C. and Lalonde S. V. (2019) Constraining the rise of oxygen with oxygen isotopes. Nat. Commun. 10, 4924.

Kipp M. A. and Stüeken E. E. (2017) Biomass recycling and Earth's early phosphorus cycle. Sci. Adv. 3, eaao4795.

Knauth L. P. and Lowe D. R. (2003) High Archean climatic temperature inferred from oxygen isotope geochemistry of cherts in the $3.5 \mathrm{Ga}$ Swaziland Supergroup, South Africa. Geol. Soc. Am. Bull. 115, 566-580.

Kump L. R. (2008) The rise of atmospheric oxygen. Nature 451, 277-278.

Kump L. R. and Barley M. E. (2007) Increased subaerial volcanism and the rise of atmospheric oxygen 2.5 billion years ago. Nature 448, 1033-1036.

Labidi J., Cartigny P. and Jackson M. G. (2015) Multiple sulfur isotope composition of oxidized Samoan melts and the implications of a sulfur isotope 'mantle array' in chemical geodynamics. Earth Planet. Sci. Lett. 417, 28-39.

Lackey J. S., Erdmann S., Hark J. S., Nowak R. M., Murray K. E., Clarke D. B. and Valley J. W. (2011) Tracing garnet origins in granitoid rocks by oxygen isotope analysis: Examples from the South Mountain Batholith, Nova Scotia. Can. Mineral. 49, 417-439.

LaFlamme C., Fiorentini M. L., Lindsay M. D. and Bui T. H. (2018a) Atmospheric sulfur is recycled to the crystalline continental crust during supercontinent formation. Nat. Commun. 9, 4380.

LaFlamme C., Jamieson J. W., Fiorentini M. L., Thébaud N., Caruso S. and Selvaraja V. (2018b) Investigating sulfur pathways through the lithosphere by tracing mass independent fractionation of sulfur to the Lady Bountiful orogenic gold deposit, Yilgarn Craton. Gondwana Res. 58, 27-38.

LaFlamme C., Martin L., Jeon H., Reddy S. M., Selvaraja V., Caruso S., Bui T. H., Roberts M. P., Voute F., Hagemann S., Wacey D., Littman S., Wing B., Fiorentini M. and Kilburn M. R. (2016) In situ multiple sulfur isotope analysis by SIMS of pyrite, chalcopyrite, pyrrhotite, and pentlandite to refine magmatic ore genetic models. Chem. Geol. 444, 1-15.

Larbi Y., Stevenson R., Breaks F., Machado N. and Gariépy C. (1999) Age and isotopic composition of late Archean leucogranites: implications for continental collision in the western Superior Province. Can. J. Earth Sci. 36, 495-510.

Li X.-H., Long W.-G., Li Q.-L., Liu Y., Zheng Y.-F., Yang Y.-H., Chamberlain K. R., Wan D.-F., Guo C.-H., Wang X.-C. and Tao H. (2010) Penglai Zircon Megacrysts: A Potential New Working Reference Material for Microbeam Determination of Hf-O Isotopes and U-Pb Age. Geostand. Geoanal. Res. 34, 117134.

Liebmann J., Spencer C. J., Kirkland C. L., Bucholz C., He X., Santosh M., Xia X. P., Martin L. and Evans N. J. (2021a) Emergence of continents above sea-level influences sediment melt composition. Terra Nov. doi.10.1111/ter.12531.

Liebmann J., Spencer C. J., Kirkland C. L., Xia X.-P. and Bourdet J. (2021) Effect of water on $\delta 18 \mathrm{O}$ in zircon. Chem. Geol. 574, 120243.

Lompo M. (2009) Geodynamic evolution of the 2.25-2.0 Ga Palaeoproterozoic magmatic rocks in the Man-Leo Shield of the West African Craton. A model of subsidence of an oceanic plateau. Geol. Soc. Lond. Spec. Publ. 323, 231-254.

Luo G., Ono S., Beukes N. J., Wang D. T., Xie S. and Summons R. E. (2016) Rapid oxygenation of Earth's atmosphere 2.33 billion years ago. Sci. Adv. 2.

Lyons J. R. (2007) Mass-independent fractionation of sulfur isotopes by isotope-selective photodissociation of $\mathrm{SO} 2$. Geophys. Res. Lett. 34, 1-5.

Lyons T. W., Reinhard C. T. and Planavsky N. J. (2014) The rise of oxygen in Earth's early ocean and atmosphere. Nature 506, 307-315.

Mattey D., Lowry D. and Macpherson C. (1994) Oxygen isotope composition of mantle peridotite. Earth Planet. Sci. Lett. 128, 231-241.

Mikkola P., Huhma H., Heilimo E. and Whitehouse M. (2011) Archean crustal evolution of the Suomussalmi district as part of the Kianta Complex, Karelia: Constraints from geochemistry and isotopes of granitoids. Lithos 125, 287-307.

Ono S., Eigenbrode J. L., Pavlov A. A., Kharecha P., Rumble D., Kasting J. F. and Freeman K. H. (2003) New insights into Archean sulfur cycle from mass-independent sulfur isotope records from the Hamersley Basin, Australia. Earth Planet. Sci. Lett. 213, 15-30.

Ono S., Wing B., Johnston D., Farquhar J. and Rumble D. (2006) Mass-dependent fractionation of quadruple stable sulfur isotope system as a new tracer of sulfur biogeochemical cycles. Geochim. Cosmochim. Acta 70, 2238-2252.

Ozaki K., Thompson K. J., Simister R. L., Crowe S. A. and Reinhard C. T. (2019) Anoxygenic photosynthesis and the delayed oxygenation of Earth's atmosphere. Nat. Commun. 10, 3026.

Page F. Z., Fu B., Kita N. T., Fournelle J., Spicuzza M. J., Schulze D. J., Viljoen F., Basei M. A. S. and Valley J. W. (2007) Zircons from kimberlite : New insights from oxygen isotopes, trace 
elements, and $\mathrm{Ti}$ in zircon thermometry. Geochim. Cosmochim. Acta 71, 3887-3903.

Paris G., Adkins J. F., Sessions A. L., Webb S. M. and Fischer W. W. (2014) Neoarchean carbonate-associated sulfate records positive 33S anomalies. Science (80-.) 346, 739-741.

Parra-Avila L. A., Baratoux L., Eglinger A., Fiorentini M. L. and Block S. (2019) The Eburnean magmatic evolution across the Baoulé-Mossi domain: Geodynamic implications for the West African Craton. Precambrian Res. 332, 105392.

Pavlov A. A. and Kasting J. F. (2002) Mass-Independent Fractionation of Sulfur-Isotopes in Archean Sediments: Strong Evidence for an Anoxic Archean Atmosphere. Astrobiology 2.

Payne J. L., Hand M., Pearson N. J., Barovich K. M. and Mcinerney D. J. (2015) Crustal thickening and clay: Controls on $\mathrm{O}$ isotope variation in global magmatism and siliciclastic sedimentary rocks. Earth Planet. Sci. Lett. 412, 70-76.

Peck W. H. and Smith M. S. (2005) Cordierite-gedrite rocks from the Central Metasedimentary Belt boundary thrust zone (Grenville Province, Ontario): Mesoproterozoic metavolcanic rocks with affinities to the Composite Arc Belt. Can. J. Earth Sci. 42, 1815-1828.

Peck W. H. and Valley J. W. (2000) Genesis of cordierite - gedrite gneisses, central metasedimentary belt boundary thrust zone, Grenville Province, Ontario, Canada. Can. Mineral. 38, 511524.

Percival J. A. (1989) A regional perspective of the Quetico metasedimentary belt, Superior Province, Canada. Can. J. Earth Sci. 26, 677-693.

Percival J. A., Skulski T., Sanborn-Barrie M., Stott G. M., Leclair A. D., Corkery M. T. and Boily M. (2012) Geology and tectonic evolution of the Superior Province, Canada. In Tectonic Styles in Canada: The Lithoprobe Perspective, Special Paper, pp. 321-378.

Petersson A., Scherstén A., Kristinsdóttir B., Kemp A. and Whitehouse M. (2018) Birimian crustal growth in the West African Craton: $\mathrm{U}-\mathrm{Pb}, \mathrm{O}$ and $\mathrm{Lu}-\mathrm{Hf}$ isotope constraints from detrital zircon in major rivers. Chem. Geol. 479, 259-271.

Pidgeon R. T., Nemchin A. A. and Whitehouse M. J. (2017) The effect of weathering on U-Th-Pb and oxygen isotope systems of ancient zircons from the Jack Hills, Western Australia. Geochim. Cosmochim. Acta 197, 142-166.

Planavsky N. J., Asael D., Hofmann A., Reinhard C. T., Lalonde S. V., Knudsen A., Wang X., Ossa Ossa F., Pecoits E., Smith A. J. B., Beukes N. J., Bekker A., Johnson T. M., Konhauser K. O., Lyons T. W. and Rouxel O. J. (2014) Evidence for oxygenic photosynthesis half a billion years before the Great Oxidation Event. Nat. Geosci. 7, 283-286.

Planavsky N. J., Rouxel O. J., Bekker A., Lalonde S. V., Konhauser K. O., Reinhard C. T. and Lyons T. W. (2010) The evolution of the marine phosphate reservoir. Nature 467, 1088-1090.

Poulson S. R. and Ohmoto H. (1989) Devolatilization equilibria in graphite-pyrite-pyrrhotite bearing pelites with application to magma-pelite interaction. Contrib. Mineral. Petrol. 101, 418425.

Pufahl P. K. and Hiatt E. E. (2012) Oxygenation of the Earth's atmosphere-ocean system: A review of physical and chemical sedimentologic responses. Mar. Pet. Geol. 32, 1-20.

Reed J. C., Bickford M. E., Premo W. R., Aleinikoff J. N. and Pallister J. S. (1987) Evolution of the Early Proterozoic Colorado province: Constraints from U-Pb geochronology. Geology 15, 861.

Reinhard C. T., Planavsky N. J., Gill B. C., Ozaki K., Robbins L. J., Lyons T. W., Fischer W. W., Wang C., Cole D. B. and
Konhauser () Evolution of the global phosphorus cycle. Nature 541, 386-389.

Rosing M. T. and Frei R. (2004) U-rich Archaean sea-floor sediments from Greenland - indications of $>3700$ Ma oxygenic photosynthesis. Earth Planet. Sci. Lett. 217, 237-244.

Santosh M. (2010) Assembling North China Craton within the Columbia supercontinent: The role of double-sided subduction. Precambrian Res. 178, 149-167.

Savin S. M. and Epstein S. (1970) The oxygen and hydrogen isotope geochemistry of clay minerals. Geochim. Cosmochim. Acta 34, 25-42.

Schmitt, A.K., Magee, Jr. C.W., Williams, I.S., Holden, P., Ireland, T.R., DiBugnara, D.L., Bodorkos, S., 2019. Oxygen isotopic heterogeneity in the Temora-2 reference zircon. Record 2019/04. Geoscience Australia, Canberra. http://dx.doi.org/10. 11636/Record.2019.004.

Scott C., Lyons T. W., Bekker A., Shen Y., Poulton S. W., Chu X. and Anbar A. D. (2008) Tracing the stepwise oxygenation of the Proterozoic ocean. Nature 452, 456-459.

Shand S. J. (1943) Eruptive Rocks: their Genesis, Composition, Classification, and their Relation to Ore-Deposit; with a Chapter on Meteorites. Thomas Murby, London.

Sharp Z. D. (1990) A laser-based microanalytical method for the in situ determination of oxygen isotope ratios of silicates and oxides. Geochim. Cosmochim. Acta 54, 1353-1357.

Smit K. V., Shirey S. B., Hauri E. H. and Stern R. A. (2019) Sulfur isotopes in diamonds reveal differences in continent construction. Science (80-.) 364, 383-385.

Spencer C. J., Cawood P. A., Hawkesworth C. J., Raub T. D., Prave A. R. and Roberts N. M. W. (2014) Proterozoic onset of crustal reworking and collisional tectonics: Reappraisal of the zircon oxygen isotope record. Geology 42, 451-454.

Spencer C. J., Murphy J. B., Kirkland C. L., Liu Y. and Mitchell R. N. (2018) Was the supercontinent cycle activated by a Palaeoproterozoic tectono-magmatic lull? Nat. Geosci. 11, 97101.

Spencer C. J., Partin C. A., Kirkland C. L., Raub T. D., Liebmann J. and Stern R. A. (2019) Paleoproterozoic increase in zircon $\delta 18 \mathrm{O}$ driven by rapid emergence of continental crust. Geochim. Cosmochim. Acta 257, 16-25.

Stacey J. S. and Kramers J. D. (1975) Approximation of terrestrial lead isotope evolution by a two-stage model. Earth Planet. Sci. Lett. 26, 207-221.

Steiger R. H. and Jäger E. (1977) Subcommission on geochronology: Convention on the use of decay constants in geo- and cosmochronology. Earth Planet. Sci. Lett. 36, 359-362.

Stern R. A., Bodorkos S., Kamo S. L., Hickman A. H. and Corfu F. (2009) Measurement of SIMS instrumental mass fractionation of $\mathrm{Pb}$ isotopes during zircon dating. Geostand. Geoanal. Res. 33(2), 145-168.

Stevens G., Villaros A. and Moyen J.-F. (2007) Selective peritectic garnet entrainment as the origin of geochemical diversity in Stype granites. Geology 35, 9 .

Taylor H. P. (1980) The effects of assimilation of country rocks by magmas on $18 \mathrm{O} / 16 \mathrm{O}$ and $87 \mathrm{Sr} / 86 \mathrm{Sr}$ systematics in igneous rocks. Earth Planet. Sci. Lett. 47, 243-254.

Tindle A. G., Selway J. B. and Breaks F. W. (2002) Electron microprobe and bulk analyses of fertile peraluminous granites and related rare-element pegmatites, Superior Province, northwest and northeast Ontario: Operation Treasure Hunt, 111. Ontario Geol. Surv. Misc Release Data.

Tyrrell T. (1999) The relative influences of nitrogen and phosphorus on oceanic primary production. Nature 400, 525-531.

Väisänen M., Mänttäri I., Kriegsman L. M. and Hölttä P. (2000) Tectonic setting of post-collisional magmatism in the Palaeo- 
proterozoic Svecofennian Orogen, SW Finland. Lithos 54, 6381.

Valley J. W. (2003) Oxygen Isotopes in Zircon. Rev. Mineral. Geochemistry 53, 343-385.

Valley J. W., Bindeman I. N. and Peck W. H. (2003) Empirical calibration of oxygen isotope fractionation in zircon. Geochim. Cosmochim. Acta 67, 3257-3266.

Valley J. W., Chiarenzelli J. R. and McLelland J. M. (1994) Oxygen isotope geochemistry of zircon. Earth Planet. Sci. Lett. 126, $187-206$.

Valley J. W., Kitchen N., Kohn M. J., Niendorf C. R. and Spicuzza M. J. (1995) UWG-2, a garnet standard for oxygen isotope ratios: Strategies for high precision and accuracy with laser heating. Geochim. Cosmochim. Acta 59, 5223-5231.

Valley J. W., Lackey J. S., Cavosie A. J., Clechenko C. C., Spicuzza M. J., Basei M. A. S., Bindeman I. N., Ferreira V. P., Sial A. N., King E. M., Peck W. H., Sinha A. K. and Wei C. S. (2005) 4.4 billion years of crustal maturation: Oxygen isotope ratios of magmatic zircon. Contrib. Mineral. Petrol. 150, 561-580.

Vielzeuf D. (2005) Oxygen isotope heterogeneities and diffusion profile in composite metamorphic-magmatic garnets from the Pyrenees. Am. Mineral. 90, 463-472.

Ward L. M., Kirschvink J. L. and Fischer W. W. (2016) Timescales of Oxygenation Following the Evolution of Oxygenic Photosynthesis. Orig. Life Evol. Biosph. 46, 51-65.

Warke M. R., Di Rocco T., Zerkle A. L., Lepland A., Prave A. R., Martin A. P., Ueno Y., Condon D. J. and Claire M. W. (2020) The Great Oxidation Event preceded a Paleoproterozoic "snowball Earth". Proc. Natl. Acad. Sci. 202003090.

Watts K. E., John D. A., Colgan J. P., Henry C. D., Bindeman I. N. and Valley J. W. (2019) Oxygen isotopic investigation of silicic magmatism in the Stillwater caldera complex, Nevada: Generation of large-volume, low- $\delta 180$ rhyolitic tuffs and assessment of their regional context in the Great Basin of the western United States. GSA Bull. 131, 1133-1156.

Whitehill A. R., Jiang B., Guo H. and Ono S. (2015) SO2 photolysis as a source for sulfur mass-independent isotope signatures in stratospehric aerosols. Atmos. Chem. Phys. 15, 1843-1864.

Whitehouse M. J. (2013) Multiple Sulfur Isotope Determination by SIMS: Evaluation of Reference Sulfides for $\Delta 33 \mathrm{~S}$ with Observations and a Case Study on the Determination of $\Delta 36 \mathrm{~S}$. Geostand. Geoanal. Res. 37, 19-33.

Wiedenbeck M., Hanchar J. M., Peck W. H., Sylvester P., Valley J., Whitehouse M., Kronz A., Morishita Y., Nasdala L., Fiebig J., Franchi I., Girard J. P., Greenwood R. C., Hinton R., Kita N., Mason P. R. D., Norman M., Ogasawara M., Piccoli P. M., Rhede D., Satoh H., Schulz-Dobrick B., Skår Spicuzza M. J., Terada K., Tindle A., Togashi S., Vennemann T., Xie Q. and Zheng Y. F. (2004) Further characterisation of the 91500 zircon crystal. Geostand. Geoanal. Res. 28, 9-39.

Wingate M. T. D. and Kirkland C. L. (2015) Introduction to geochronology information released in 2015. Geol Surv. West. Aust., 5p.

Woodcock N. H. (2004) Life span and fate of basins. Geology 32, 685.

Wu F., Jahn B., Wilde S. A., Lo C., Yui T., Lin Q., Ge W. and Sun D. (2003) Highly fractionated I-type granites in NE China (I): geochronology and petrogenesis. Lithos 66, 241-273.

Yang X.-M., Drayson D. and Polat A. (2019) S-type granites in the western Superior Province: a marker of Archean collision zones. Can. J. Earth Sci. 56, 1409-1436.

Zhao G., Wilde S. A., Cawood P. A. and Lu L. (1999) Tectonothermal history of the basement rocks in the western zone of the North China Craton and its tectonic implications. Tectonophysics 310, 37-53.

Zhao G. and Zhai M. (2013) Lithotectonic elements of Precambrian basement in the North China Craton: Review and tectonic implications. Gondwana Res. 23, 1207-1240.

Associate editor: Shuhei Ono 